\title{
İşe Yabancılaşmada Duygusal Zekâ, Sosyal Destek ve Duygusal Emek Gösterimleri
}




\section{(C) Copyright 2021}

Bu kitabın, basım, yayın ve satış hakları Akademisyen Kitabevi A.Ş.'ye aittir. Anılan kuruluşun izni alınmadan kitabın tümü ya da bölümleri mekanik, elektronik, fotokopi, manyetik kağıt ve/veya başka yöntemlerle çoğaltılamaz, basılamaz, dağıtılamaz. Tablo, şekil ve grafikler izin alınmadan, ticari amaçh kullanılamaz. Bu kitap T.C. Kültür Bakanlı̆̆ bandrolü ile satılmaktadır.

\section{ISBN}

978-625-7496-92-6

Kitap Adı

İşe Yabancilaşmada Duygusal Zekâ, Sosyal Destek

ve Duygusal Emek Gösterimleri

Yazar
Selçuk YEKE
ORCID iD: 0000-0002-1953-62
Yayın Koordinatörü
Yasin DİLMEN
Sayfa ve Kapak Tasarımı
Akademisyen Dizgi Ünitesi
Yayıncı Sertifika No
47518
Baskı ve Cilt
Vadi Matbaacılık
Bisac Code
PSY000000
DOI
10.37609/akya.720

GENEL DAĞITIM

Akademisyen Kitabevi A.Ş.

Halk Sokak 5 / A

Yenişehir / Ankara

Tel: o312 4311633

siparis@akademisyen.com

www.akademisyen.com 


\section{ÖNSÖZ}

Yabancılaşma kavramı yıllardan bu yana farklı disiplinler çerçevesinde ele alınmıştır. Yabancılaşma ekonomi, sosyoloji, felsefe ve tinbilimi gibi alanlar içerisinde farklı düşünürler tarafindan incelenmiştir. Esasında bu kitabın ana konusu olan işe yabancılaşma kavramı da bir tür yabancılaşma çeşidi olup, günümüzde birçok işletme çalışanlarının yaşadığı bir duygu haline dönüşmektedir. Çalışanları olumsuz yönde etkileyen, mutsuz olmalarına neden olan ve işten ayrılma eğilimini ortaya çıkarabilen işe karşı yabancılaşma duygusu organizasyonları de olumsuz yönde etkilemektedir. Çalı̧̧anlarının işe karşı bağll1ı̆̆ını oluşturamayan, çalışanların işinden tatmin olmasını sağlayacak uygulamaları hayata geçiremeyen ve nihayetinde çalışanlarını kendi bünyesinde tutamayan birçok işletme bulunmaktadır. Dolayısıyla hem çalışanları hem de organizasyonları önemli ölçüde etkileyen işe yabancılaşma olgusu bu kitabın esas unsurunu oluşturmaktadır.

Bu kitap akademik birikimimin bir yansıması olup, doktora tezimin de önemli bir parçasını oluşturmaktadır. Sahip olduğum akademik birikimin oluşmasına önemli katkılar sağlayan, farklı bakış açılarını kazandıran ve akademik kariyerim boyunca her zaman desteğini hissettiğim sevgili hocalarım Prof. Dr. İbrahim PINAR ve Prof. Dr. Iş1l PEKDEMİR'e çok teşekkür ederim. Son olarak hayatımda çok özel yeri olan, varlığıyla beni motive eden ve akademik kariyerim boyunca her zaman bana destek veren kıymetli anneme şükranlarımı sunarım.

İSTANBUL, 2021 SELÇUK YEKE 



\section{İÇINDEKILER}

\section{Bölüm 1}

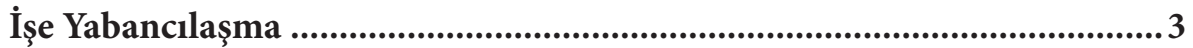

1.1 Yabanclaşma Kavramı..............................................................................

1.1.1 Yabancılaşmaya Yönelik Yaklaşımlar...................................................

1.1.1.1 Karl Marx ve Yabancılaşma Anlayışı ............................................7

1.1.1.2 W. F. Hegel ve Yabancilaşma Anlayışı........................................ 10

1.1.1.3 E. Fromm ve Yabancılaşma Anlayışı ......................................... 13

1.1.1.4 Georg Simmel ve Yabancılaşma Anlayışı ................................. 16

1.1.1.5 Herbert Marcuse ve Yabancılaşma Anlayışı ............................ 19

1.1.1.6 Ludwig Feuerbach ve Yabancılaşma Anlayışı.......................... 21

1.1.1.7 Charles Wright Mills ve Yabancılaşma Anlayışı .................... 22

1.1.1.8 Emile Durkheim ve Yabancılaşma Anlayışı ........................... 24

1.1.1.9 Melvin Seeman ve Yabancılaşma Anlayış1 ............................... 26

1.1.2 Yabancılaşma Çeşitleri .................................................................. 27

1.1.2.1 İnsanın Topluma Yabancılaşması........................................... 27

1.1.2.2 Toplumun Yabancılaşması ........................................................ 29

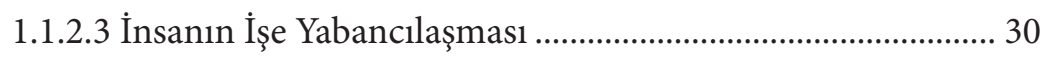

1.2 İşe Yabancılaşma Kavramı.......................................................................... 31

1.3 İşe Yabancılaşmanın Boyutları..................................................................... 33

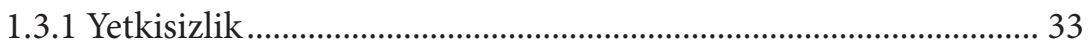

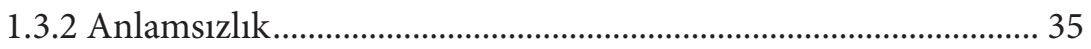

1.3.3 Normsuzluk (Kuralsılık) ........................................................... 37

1.3.4 Yalıtılmışlık ................................................................................... 39

1.3.5 Kendine Yabancilaşma .................................................................... 40

1.4 İşe Yabancılaşmanın Organizasyonlar Üzerindeki Sonuçları............... 42

1.5 İşe Yabancılaşmanın Çalışanlar Üzerindeki Sonuçları ............................ 43

1.6 İşe Yabancılaşmanın Önlenmesinde Kullanılabilecek

Temel Yöntemler ................................................................................. 45

1.6.1 Çatı̧̧ma Yönetimi........................................................................... 45

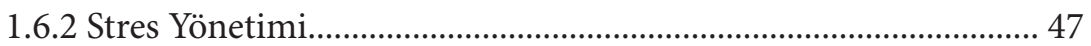

1.6.3 Yönetime Katılma ............................................................................ 48

1.6.4 Diğer Örgütsel Uygulamalar .......................................................... 49 


\section{Bölüm 2}

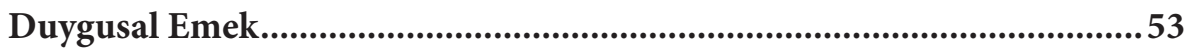

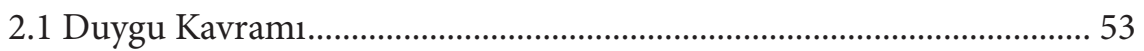

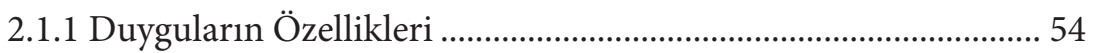

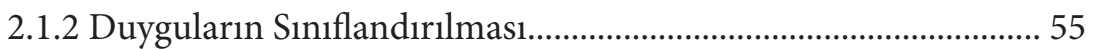

2.1.3 Duyguların Organizasyonlardaki Yeri ve Önemi ........................... 56

2.2 Duygusal Emek Kavramı ........................................................................ 58

2.2.1 Duygusal Emeğin Kuramsal Temelleri .......................................... 59

2.2.1.1 Hochschild'in Duygusal Emek Kuram1.................................. 59

2.2.1.2 Ashforth ve Humprey'in Duygusal Emek Kuram1 ............... 61

2.2.1.3 Morris ve Feldman’n Duygusal Emek Kuramı.................... 62

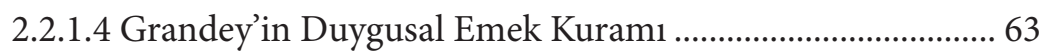

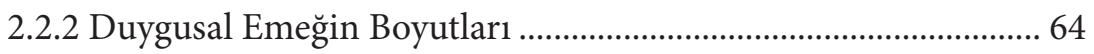

2.2.2.1 Yüzeysel Rol Yapma Davranış1 .....................................64

2.2.2.2 Derinden Rol Yapma Davranı̧̧1 .....................................65

2.2.2.3 Doğal Davranış ............................................................ 67

2.2.3 Yüzeysel Rol Yapma Davranışı, Derinden Rol Yapma

Davranışı ve Doğal Davranışı Etkileyen Faktörler ......................... 68

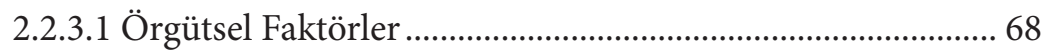

2.2.3.1.1 Duygu Gösterim Kuralları ............................................. 69

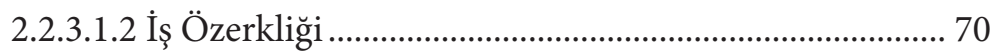

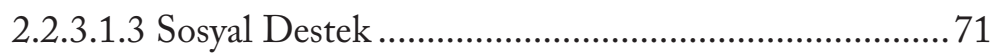

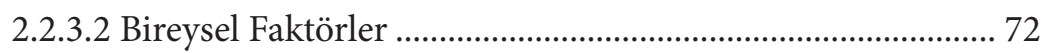

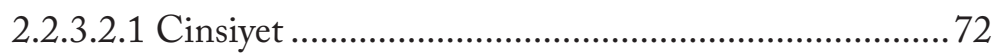

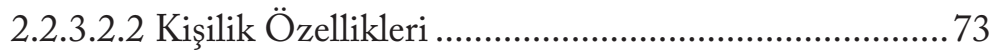

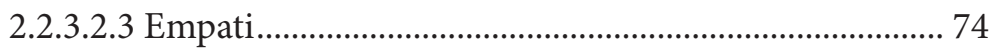

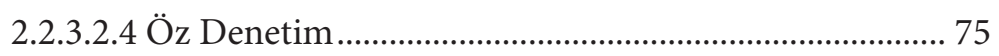

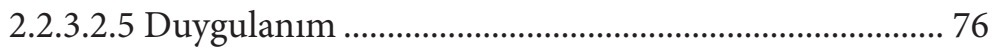

2.2.3.2.6 Duygusal Zekâ .................................................................. 77

2.2.4 Yüzeysel Rol Yapma Davranışı, Derinden Rol Yapma

Davranışı ve Doğal Davranışın Organizasyonlar ve Çalışanlar Üzerindeki Sonuçları ................................................. 77

2.2.5 Yüzeysel Rol Yapma Davranışı İle İşe Yabancılaşma Arasındaki İlişkiye Yönelik Çalışmalar ............................................ 82

2.2.6 Derinden Rol Yapma Davranışı İle İşe Yabancılaşma Arasındaki İlişkiye Yönelik Çalışmalar... 
2.2.7 Doğal Davranış İle İşe Yabancılaşma Arasındaki

İlişkiye Yönelik Çalışmalar 90

\section{Bölüm 3}

Duygusal Zekâ.................................................................................................93

3.1 Duygusal Zekâ Modelleri .......................................................................... 95

3.1.1 Mayer ve Salovey'in Duygusal Zekâ Modeli .................................. 95

3.1.2 Daniel Goleman' in Duygusal Zekâ Modeli ................................... 96

3.1.3 Reuven Bar-On’un Duygusal Zekâ Modeli...................................... 97

3.1.4 Cooper ve Sawaf'ın Duygusal Zekâ Modeli .................................... 99

3.2 Duygusal Zekânın Boyutları ................................................................... 100

3.2.1 Kişilerin Kendi Duygularını Değerlendirmesi.............................. 100

3.2.2 Kişilerin Başkalarının Duygularını Değerlendirmesi ................. 101

3.2.3 Duyguların Yönetimi................................................................ 102

3.2.4 Duygulardan Yararlanılması......................................................... 104

3.3 Duygusal Zekânın Organizasyonlar ve Çalışanlar Açısından Önemi ve Ortaya Çıkardığ 1 Sonuçlar ..................................................... 105

3.4 Duygusal Zekâ İle İşe Yabancılaşma Arasındaki İlişkiye Yönelik Yapılan Çalışmalar ..................................................................... 107

3.5 Duygusal Zekâ İle Yüzeysel Rol Yapma Davranışı Arasındaki İlişkiye Yönelik Yapılan Çalışmalar....................................................... 109

3.6 Duygusal Zekâ İle Derinden Yapma Davranışı Arasındaki İlişkiye Yönelik Yapılan Çalışmalar......................................................... 112

3.7 Duygusal Zekâ İle Doğal Davranış Arasındaki İlişkiye Yönelik Yapılan Çalışmalar

\section{Bölüm 4}

Sosyal Destek

4.1 Sosyal Destek Kaynakları ..................................................................... 120

4.2 Sosyal Desteğin Fonksiyonları............................................................... 122

4.3 Sosyal Desteğin Boyutları..................................................................... 123

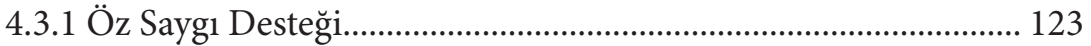

4.3.2 Fiziksel Destek........................................................................... 125

4.3.3 Kişisel Konularda Destek........................................................... 126

4.3.4 Aidiyet Desteği ............................................................................... 127

4.4 Sosyal Desteğin Organizasyonlar ve Çalışanlar Açısından

Önemi ve Ortaya Çıkardığı Sonuçlar. 128 
4.5 Sosyal Destek İle İşe Yabancılaşma Arasındaki İlişkiye Yönelik Yapılan Çalışmalar.

4.6 Sosyal Destek İle Yüzeysel Rol Yapma Davranışı Arasındaki İlişkiye Yönelik Yapılan Çalışmalar...

4.7 Sosyal Destek İle Derinden Rol Yapma Davranışı Arasındaki İlişkiye Yönelik Yapılan Çalışmalar..

4.8 Sosyal Destek İle Doğal Davranış Arasındaki İlişkiye Yönelik Yapılan Çalışmalar

4.9 Duygusal Zekâ İle Sosyal Destek Arasındaki İlişkiye Yönelik Yapılan Çalışmalar..

KAYNAKLAR 147 


\section{KAYNAKLAR}

Abraham, Rebecca: 1999 “The Impact of Emotional Dissonance On Organizational Commitment and Intention To Turnover", The Journal of Psychology, 133 (4), 441-455.

Adler, Alfred: 2016 İnsanı Tanıma Sanatı, Çev. Kâmuran Şipal, Say Yayınları, 1-152.

Affinnih, Yahya H.: 1997 "A Critical Reexamination of Alienation", The Social Science Journal, 34 (3), 383 - 387.

Akdemir, Ferhat: 2003 “Feuerbach’n Antropolojik Ateizmi ve Teistik Açıdan Değerlendirilmesi”, Ondokuz Mayıs Üniversitesi İlahiyat Fakültesi Dergisi, 14 (14-15), 341-357.

Akkirman, Ali Deniz: 1998 "Etkin Çatışma Yönetimi ve Müdahale Stratejileri”, Dokuz Eylül Üniversitesi İktisadi ve İdari Bilimler Fakültesi Dergisi, 13 (2), 1-11.

Akyıldız, Hüseyin: 1998 “Bireysel ve Toplumsal Boyutlarıyla Yabancılaşma, Süleyman Demirel Üniversitesi, İktisadi ve İdari Bilimler Fakültesi Dergisi, Cilt 3, 163-176.

Alvelos, Rita \& Ferreira, Aristides I.: 2015 "The Mediating Role of Social Support In The Evaluation of Training Effectiveness", European Journal of Training and Development, 39 (6), 484-503.

Alver, Köksal: 2004 “Kitap Değerlendirmesi (Modern Kültürde Çatışma)”, İstanbul Üniversitesi Edebiyat Fakültesi Sosyoloji Dergisi, 3 (8), 191-195.

Andireş, Alina Maria: 2011 "Positive and Negative Emotions Within The Organizational Context", Global Journal of Human Social Science, 11 (9), 27-39.

Angels, Jeremy: 2008 "Democratic Alienation", Rhetoric and Public Affairs, 11 (3), 471-481.

Archibald, W. Peter: 1978 "Using Marx's Theory of Alienation Empirically”, Theory and Society, $6(1), 119-132$.

Arditi, Jorge: 1996 "Simmel's Theory of Alienation and The Decline of The Nonrational", Sociological Theory, 14 (2), 93-108.

Aron, Raymond: 1998 Main Currents In Sociological Thought, Transaction Publishers, 1-354.

Ashforth, Blake E \& Humphrey, Ronald H.: 1993 "Emotional Labor In Service Roles: The Influence of Identity", Academy of Management Review, 18 (1), 88-115.

Ashforth, Blake E \& Humphrey, Ronald H.: 1995 “Emotion In The Workplace: A Reappraisal”, Human Relations, 48 (2), 1995, 97 - 125.

Ashkanasy, Neal M \& Daus, Catherine S.: 2002 Emotion In The Workplace: The New Challenge For Managers, The Academy of Management Executive, 16 (1), 2002, 76 - 86.

Ashkanasy, Neal M.: 2003 "Emotions In Organizations: A Multi-Level Perspective", Multi-Level Issues In Organizational Behavior and Strategy, Sayı 2, 9-54.

Aslan, Hüseyin: 2018 "Duygusal Emek İle İşe Yabancılaşma İlişkisinde Psikolojik Sermayenin Etkisi: Otel İşletmelerinde Bir Alan Araştırması”, Hasan Kalyoncu Üniversitesi Sosyal Bilimler Enstitüsü, Doktora Tezi, 1-221.

Atsan, Nuray: 2017 "Karar Vermede Çatışma Kuramı ve Özsaygı İlişkisine Yönelik Kültürel Bir İnceleme”, Süleyman Demirel Üniversitesi İktisadi ve İdari Bilimler Fakültesi Dergisi, 22 (1), 63-73.

Aydın, Derya Güler: 2010 "Kapitalizmde Bireyin Sorgulanması: Yabancılaşma ve Demir Kafes”, Amme İdaresi Dergisi, 43 (2), 17-32.

Aydoğan, Emine: 2015 “Marx ve Öncüllerinde Yabancilaşma Kavramı”, Atatürk Üniversitesi Edebiyat Fakültesi Sosyal Bilimler Dergisi, Sayı 54, 273-281.

Aytaç, Ömer: 2004 “Örgütler: Sosyolojik Bir Perspektif”, Fırat Üniversitesi Sosyal Bilimler Dergisi, 14 (1), 189-217.

Aytaç, Ömer: 2005 “Modern Bürokrasiler ve Yabancılaşma Ethosu”, Firat Üniversitesi Sosyal Bilimler Dergisi, 15 (2), 319-348.

Bailey, Catherine \& Madden, Adrian: 2016 "What Makes Work Meaningul-Or Meaningless", MIT Sloan Management Review, 57 (4), 53-61.

Banai, Moshe \& Reisel, William D.: 2007 “The Influence of Supportive Leadership and Job Cha- 
racteristics On Work Alienation: A Six-Country Investigation", Journal of World Business, Say1 42, 463-476.

Barakat, Halim: 1969 "Alienation: A Process of Encounter Between Utopia and Reality", The British Journal of Sociology, 20 (1), 1-10.

Barbalet, Jack: 2006 "Emotion”, Contexts, 5 (2), 51-53.

Bar-On, Reuven.: 2000 "Emotional and Social Intelligence: Insight From The Emotional Quotient Inventory", The Handbook of Emotional Intelligence: Theory, Development, Assessment and Application At Home, School, and In The Workplace, Ed. Bar-On, R ve Parker, J. D. A., Jossey-Bass Publishers, 3-528.

Bar-On, Reuven: 2006 “The Bar-On Model of Emotional-Social Intelligence (ESI)”, Psicothema, Say1 18, 13-25.

Bar-On, Reuven: 2007 "How Important Is It to Educate People To Be Emotionally Intelligent, and Can It Be Done?", Educating People To Be Emotionally Intelligent, Ed. Bar-On, R., Maree, J. G ve Elias, M. J., Praeger Publishers, 1-323.

Barut, Yasin: 2015 "Duygusal Zeka ve İletişim Becerileri İlişkisi: Örgüt Kültürünün Aracı Rolü (İzmir Bozyaka Eğitim Araştırma Hastanesi ve Kent Hastanesinde Görevli Sağlık Çalışanlar1 Örneği)", Yaşar Üniversitesi Sosyal Bilimler Enstitüsü, Doktora Tezi, 1-175.

Baş, Selma: 2003 “Türk Hikâyeciliğinde Yabancılaşma”, Yüzüncü Yıl Üniversitesi Sosyal Bilimler Enstitüsü, Doktora Tezi, 1-1038.

Bayat, Bülent: 1996 "Çimento ve Otomotiv Sektörlerinde Çalışan İşçiler Arasında Yabancılaşmanın Karşılaştırmalı Olarak Araştırılması”, Gazi Üniversitesi Sosyal Bilimler Enstitüsü, Doktora Tezi, 1-200.

Bayhan, Vehbi: 1995 “Üniversite Gençliğinde Anomi ve Yabancılaşma”, İnönü Üniversitesi Sosyal Bilimler Enstitüsü, Doktora Tezi, 12-310.

Baykal, Kazım \& Kovanc1, Ahmet: 2008 "Yönetici ve Astlar Arasındaki Anlaşmazlıkların Çözümüne Yönelik Bir Araştırma”, Havacılık ve Uzay Teknolojileri Dergisi, 3 (3), 21-38.

Bayram, Nuran., Aytaç, Serpil \& Dursun, Salih: 2012 "Emotional Labor and Burnout At Work: A Study From Turkey", International Congress On Interdisciplinary Business and Social Science, 300-305.

Becker, William J.: 2010 "Shared Display Rules and Emotional Labor In Work Teams", The University of Arizona, Doctoral Dissertation, 12-103.

Becker, William J \& Cropanzano, Russell: 2011 "Display Rules and Emotional Labor Within Work Teams", What Have We Learned? Ten Years On, Ed. Härtel, C. E. J., Ashkanasy, N. M ve Zerbe, W. J., Emerald Group Publishing Limited, Bingley, 1-363.

Begenirbaş, Memduh \& Çalışkan, Abdullah: 2014 "Duygusal Emeğin İş Performansı ve İşten Ayrılma Niyetine Etkisinde Kişilerarası Çarpıklığın Aracılık Rolü”, Business and Economics Research Journal, 5 (2), 109-127.

Begenirbaş, Memduh: 2015 "Psikolojik Sermayenin Çalışanların Duygu Gösterimleri ve İşe Yabancılaşmalarına Etkileri: Sağlık Sektöründe Bir Araştırma”, Süleyman Demirel Üniversitesi İktisadi ve İdari Bilimler Fakültesi Dergisi, 20 (3), 249-263.

Bercovitch, Jacob: 1983 "Conflict and Conflict Management In Organizations: A Framework For Analysis”, Hong Kong Journal of Public Administration, 5 (2), 104-123.

Berkovich, Izhak \& Eyal, Ori: 2018 "Principals' Emotional Support and Teachers' Emotional Reframing: The Mediating Role of Principals' Supportive Communication Strategies", Psychology In The Schools, 55 (7), 867-879.

Bhadra, Bipul Kumar: 1978 “The Political Sociology of C. Wright Mills”, McMaster University, Master of Arts In The Department of Sociology, 1-386.

Bickford, Hugh L \& Neal, Arthur G.: 1969 "Alienation and Social Learning: A Study of Students In A Vocational Training Center", Sociology of Education, 42 (2), 141-153.

Biordi, Diana Luskin \& Nicholson, Nicholas R.:2013 “Social Alienation”, Chronic Illness: Impact and Intervention, Ed. Ilene Morof Lubkin, Pamela D. Larsen, Jones and Bartlett Publishers, 
$1-669$.

Boateng, Irene Akuamoah \& Agyei, Albert: 2013 “Employee's Emotions: A Manageable Weapon For Organizations", International Journal of Human Resource Studies, 3 (4), 256-267.

Bono, Joyce E \& Vey, Meredith A: 2005 "Toward Understanding Emotional Management At Work: A Quantitative Review of Emotional Labor Research", Emotions In Organizational Behavior, Ed. Härtel, C. E. J., Zerbe, W. J ve Ashkanasy, N. M., Lawrance Erlbaum Associates Publishers, 1425.

Boratav, Hale Bolak., Sunar, Diane \& Ataca, Bilge: 2011 "Duyguları Sergileme Kuralları ve Bağlamsal Belirleyicileri: Türkiye’de Üniversite Öğrencileri İle Yapılan Bir Araştırma”, Türk Psikoloji Dergisi, 26 (68), 90-101.

Boyatzis, Richard E., Goleman, Daniel \& Rhee, Kenneth S.: 2000 "Clustering Competence In Emotional Intelligence: Insights From The Emotional Competence Inventory”, The Handbook of Emotional Intelligence: Theory, Development, Assessment, and Application At Home, School, and In The Workplace, Ed. Bar-On, R ve Parker, J. D. A., Jossey-Bass Publishers, 3-528.

Boyatzis, Richard E.: 2009 "Competencies As A Behavioral Approach To Emotional Intelligence", Journal of Management Development, 28 (9), 749-770.

Braun, Jerome: 1976 "Alienation As A Social Psychiatric Concept", International Journal of Social Psychiatry, 22 (1), 9-18.

Brennen, Bonnie: 2006 "Searching For The Sane Society: Erich Fromm's Contributions To Social Theory", Javnost-The Public, 13 (3), 7-16.

Brook, Paul: 2009 "The Alienated Heart: Hochschild's 'Emotional Labour' Thesis and The Anticapitalist Politics of Alienation", Capital \& Class, Say1 98, 7-31.

Brotheridge, Celeste M \& Grandey, Alicia A.: 2002 "Emotional Labor and Burnout: Comparing Two Perspectives of People Work", Journal of Vocational Behavior, Say1 60, 17-39.

Brown, Stephen., Bain, Paul., Broderick, Pia \& Sully, Max: 2013 "Emotional Effort and Perceived Support In Renal Nursing: A Comparative Interview Study", Journal of Renal Care, 39 (4), 246-255.

Cacioppo, John T., Hawkley, Louise C., Crawford, Elizabeth., Ernst, John M., Burleson, Mary H.,

Kowalewski, Ray B., Malarkey, William B., Cauter, Eve Van \& Berntson, Gary G.: 2002 "Loneliness and Health: Potential Mechanisms", Psychosomatic Medicine, 64 (3), 407-417.

Canbek, Mustafa: 2017 "Rol Belirsizliği ve Rol Çatışmasının, İşten Ayrılma Niyeti Üzerindeki Etkisinde Duygusal Zekanın Düzenleyici Rolü”, Gaziosmanpaşa Üniversitesi Sosyal Bilimler Enstitüsü, Doktora Tezi, 1-148.

Carmeli, Abraham: 2003 “The Relationship Between Emotional Intelligence and Work Attitudes, Behavior and Outcomes: An Examination Among Senior Managers", Journal of Managerial Psychology, 18 (8), 788-813

Cast, Alicia D \& Burke, Peter J.: 2002 “A Theory of Self-Esteem”, Social Forces, 80 (3), 1041-1068.

Celep, Banu: 2008 "İlköğretim Okulu Öğretmenlerinin İşe Yabancılaşması: Kocaeli İli Örneği”, Kocaeli Üniversitesi Sosyal Bilimler Enstitüsü, Yüksek Lisans Tezi, 1-121.

Cevizci, Ahmet: 2009 Felsefe Tarihi, Say Yayınları, İstanbul, 17-1337.

Ceylan, Adnan \& Sulu, Seyfettin: 2011 "Organizational Injustice and Work Alienation", Ekonomika a Management, Say1 2, 65-78.

Choi, Woojae: 2013 "Moderating Role of Organizational Citizenship Behavior On The Relationship Between Emotional Labor and Task Performance", Journal of Convergence Information Technology, 8 (12), 397-402.

Chen, Ziguang., Sun, Hongwei., Lam, Wing., Hu, Qing., Huo, Yuanyuan \& Zhong, Jian An: 2012 "Chinese Hotel Emloyees In The Smiling Masks: Roles of Job Satisfaction, Burnout, and Supervisory Support In Relationships Betwen Emotional Labor and Performance", The International Journal of Human Resource Management, 23 (4), 826 - 845. 
Cheung, Francis Yue Lok \& Tang, Catherine So Kum: 2010 "Effects of Age, Gender, and Emotional Labor Strategies On Job Outcomes: Moderated Mediation Analyses", Applied Psychology: Health and Well-Being, 2 (3), 323-339.

Cheung, Francis Yue Lok \& Cheung, Ray Yu Hin: 2013 "Effect of Emotional Dissonance On Organizational Citizenship Behavior: Testing The Stressor - Strain Outcome Model", The Journal of Psychology, 147 (1), 89-103.

Cheung, Francis Y. L \& Miu-Chi Lun, Vivian: 2015 "Relation Between Emotional Labor and Organizational Citizenship Behavior: An Investigation Among Chinese Teaching Professionals", The Journal of General Psychology, 142 (4), 253-272.

Chiaburu, Dan S., Thundiyil, Tomas \& Wang, Jiexin: 2014 "Alienation and Its Correlates: A Meta-Analysis", European Management Journal, 32 (1), 24-36.

Chou, Huei Yin: 2009 "The Effects of Job Demands and Resources On Emotional labour and Employees' Psychological Well-Being", University of Tasmania, Doctoral Dissertation, 1-219.

Chow, Wing S \& Chan, Lai Sheung: 2008 "Social Network, Social Trust and Shared Goals In Organizational Knowledge Sharing", Information \& Management, 45 (7), 458-465.

Chriss, James J.: 2007 “The Functions of the Social Bond”, Sociological Quarterly, 48 (4), 689712 .

Chu, Kay Hei Lin: 2002 “The Effects of Emotional Labor On Employee Work Outcomes”, Virginia Polytechnic Institute and State University, Doctoral Dissertation, 1- 188.

Claes, Tom: 2005 "Georg Simmel On Sex, Money and Personal Worth", Center For Ethics \& Value Enquiry, 5 (1), 1-24.

Cobb, Sidney: 1976 "Social Support As A Moderator of Life Stress", Psychosomatic Medicine, 38 (5), 1976, 300- 314.

Cohen, Sheldon \& McKay, Garth: 1984 "Social Support, Stress and the Buffering Hypothesis: A Theoretical Analysis", Handbook of Psychology and Health, Ed. A. Baum, S. E. Taylor, Jerome E. Singer, Hillsdale.

Cohen, Sheldon \& Wills, Thomas Ashby: 1985 "Stress, Social Support, and the Buffering Hypothesis", Psychological Bulletin, 98 (2), 310-357.

Cohen, Sheldon \& Syme, S. Leonard: 1985 "Issues In The Study and Application of Social Support", Social Support and Health, Ed. Cohen, S ve Syme, S. L., Academic Press, 3-390.

Cohen, Sheldon., Mermelstein, Robin., Kamarck, Tom \& Hoberman, Harry M.: 1985 "Measuring The Functional Components of Social Support", Social Support: Theory, Research and Applications, Ed. Sarason, I. G ve Sarason, B. R., NATO ASI Series, Series D: Behavioral and Social Sciences, No 24, 3-519.

Collins, David: 1996 “Control and Isolation In The Management of Empowerment”, Empowerment In Organizations, 4 (2), 29-39.

Cooper, Robert K.: 1997 “Applying Emotional Intelligence In The Workplace”, Training \& Development, Aralık, 31-38.

Costa Jr, Paul T \& McCrae, Robert R.: 1995 "Domains and Facets: Hierarchical Personality Assessment Using The Revised NEO Personality Inventory”, Journal of Personality Assessment, 64 (1), 21-50.

Cote, Stephane., Van Kleef, Gerben A \& Sy, Thomas: 2013 "The Social Effects of Emotion Regulation In Organizations", Emotional Labor In The 21st Century: Diverse Perspectives On Emotion Regulation At Work, Ed. Grandey, A. A., Diefendorff, J. M ve Rupp, D. E., Routledge Taylor \& Francis Group, 3-323.

Cowie, Roddy., Sussman, Naomi \& Ben-Ze'ev, Aaron: 2011 "Emotion: Concepts and Definitions", Emotion-Oriented Systems, Cognitive Technologies, Ed. Petta, P., Cowie, C ve Cowie, R., Springer, 3-781.

Cropanzano, Russell., Weiss, Howard M \& Elias, Steven M.: 2004 “The Impact of Display Rules and Emotional Labor On Psychological Well-Being At Work", Research In Occupational 
Stress and Well Being, Sayı 3, 4589.

Cüceloğlu, Doğan: 2006 İnsan ve Davranışı, Remzi Kitabevi, 21-586.

Çakar, Ulaş \& Arbak, Yasemin: 2004 "Modern Yaklaşımlar Işş̆ında Değişen Duygu-Zeka İlişkisi ve Duygusal Zeka”, Dokuz Eylül Üniversitesi Sosyal Bilimler Enstitüsü Dergisi, 6 (3), 23-48.

Çelik, Mazlum., Tabak, Akif., Uysal, Murat Paşa., Sığrı, Ünsal \& Türünç, Ömer: 2010 “The Relationship Between Burnout and Emotional Labour of The Employees In Hospital Sector", International Journal of Business and Management Studies, 2 (1), 47-54.

Çeliker, Nuri., Üstünel, Mehmet Fatih \& Güzeller, Cem Oktay: 2019 “The Relationship Between Emotional Labour and Burnout: A Meta-Analysis", Anatolia, 30 (3), 328-345.

Çetinkanat, Ayşe Canan \& Kösterelioğlu, Meltem Akın: 2016 "Relationship Between Quality of Work Life and Work Alienation: Research On Teachers", Universal Journal of Educational Research, 4 (8), 1778-1786.

Çiçek, Nuri: 2015 “Franz Kafka’nın Eserlerinde Yabancılaşma Problemi”, Beytulhikme Felsefe Dergisi, 5 (1), 141-162.

Dağll, Abidin \& Averbek, Emel: 2017 "The Relationship Between The Organizational Alienation and The Organizational Citizenship Behaviors of Primary School Teachers", Universal Journal of Educational Research, 5 (10), 1707-1717.

Datta, Tanmoy: 1999 "Quality of Worklife: A Human Values Approach", Journal of Human Values, 5 (2), 135-145.

Delpechitre, Duleep \& Beeler, Lisa: 2018 "Faking It: Salesperson Emotional İntelligence’s Influence On Emotional Labor Strategies and Customer Outcomes", Journal of Business \& Industrial Marketing, 33 (1), 53-71.

Demir, Fevzi \& Gerşil, Gülşen: 2008 "Çalışma Hayatında Esneklik ve Türk Hukukunda Esnek Çalışma”, Kocaeli Üniversitesi Sosyal Bilimler Enstitüsü Dergisi, Sayı 16, 68-89.

Demir, Şirvan Şen \& Demir, Mahmut: 2009 “Örgütsel İletişimde Duygusal Zekanın Rolü: Konaklama İşletmelerinde Bir Araştırma, Selçuk Üniversitesi İletişim Fakültesi Akademik Dergisi, 6 (1), 67-77.

Demir, Mahmut: 2009 "Konaklama İşletmelerinde Duygusal Zekâ, Örgütsel Sapma, Çalışma Yaşamı Kalitesi ve İşten Ayrılma Eğilimi Arasındaki İlişkinin Analizi”, Dokuz Eylül Üniversitesi Sosyal Bilimler Enstitüsü, Doktora Tezi, 1-236.

Demir, Mahmut: 2010 "Örgütsel Sapma Davranışının Kontrolünde Duygusal Zekânın Rolü: Konaklama İşletmelerinde Bir Araştırma”, Dumlupınar Üniversitesi Sosyal Bilimler Dergisi, Say1 26, 1-12.

Demircan, Pelin: 2016 “İş-Aile Çatışması-Duygusal Emek İlişkisinde Lider Desteğinin Rolü: Eğitim Üzerine Bir Araştırma”, Süleyman Demirel Üniversitesi Sosyal Bilimler Enstitüsü, Yüksek Lisans Tezi, 1-104.

Dickens, Peter: 1996 Reconstructing Nature: Alienation, Emancipation and The Division of Labour, Routledge, Londra-New York, 1-218.

Diefendorff, James M., Croyle, Meredith H \& Gosserand, Robin H.: 2005 “The Dimensionality and Antecedents of Emotional Labor Strategies", Journal of Vocational Behavior, Sayı 66, 339-357.

Diefendorff, James M., Grandey, Alicia A \& Dahling, Jason J.: 2011 "Emotional Display Rules As Work Unit Norms: A Multilevel Analysis of Emotional Labor Among Nurses", Journal of Occupational Health Psychology, 16 (2), 170-186.

Di Fabio, Annamaria \& Kenny, Maureen E.: 2012 "Emotional Intelligence and Perceived Social Support Among Italian High School Students", Journal of Career Development, 39 (5), 461475.

Di Stefano, Giovanni: 2017 "Meaningfulness and Meaninglessness of Work In Charles Bukowski”, World Futures, 73 (4-5), 271-284.

Doğan, Selen \& Demiral, Özge: 2007 “Kurumların Başarısında Duygusal Zekanın Rolü ve Öne- 
mi”, Yönetim ve Ekonomi, 4 (1), 209-230.

Doğan, Yasemin \& Özdevecioğlu, Mahmut: 2009 "Pozitif ve Negatif Duygusallığın Çalışanların Performansları Üzerindeki Etkisi”, Sosyal Ekonomik Araştırmalar Dergisi, 9 (18), 165-190.

Doğan, Sevgi: 2008 "Hegel and Marx On Alienation", Middle East Technical University, Master of Science In The Department of Psychology, 1-133.

Doğan, Erhan: 2010 "İnsanın Çevreye, Topluma ve Kendine Yabancılaşması Sorununu Radikal Şeffaflık ve Sosyal Değer Kavramları İle Yeniden Düşünmek”, Marmara Üniversitesi İ.İ.B.F. Dergisi, 29 (2), 603-617.

Doğan, Tayfun: 2013 “Beş Faktör Kişilik Özellikleri ve Öznel İyi Oluş”, Doğuş Üniversitesi Dergisi, 14 (1), 56-64.

Doğan, Edip: 2019 "Çalışanların Duygusal Zekâ Seviyelerinin ve Örgütsel Adalet Algılarının Duygusal Emek Üzerine Etkisi ve Bir Araştırma”, İnönü Üniversitesi Sosyal Bilimleri Enstitüsü, Doktora Tezi, 1-161.

Doğrul, Burcu Şefika \& Tekeli, Seda: 2010 "İş-Yaşam Dengesinin Sağlanmasında Esnek Çalışma”, Sosyal ve Beşeri Bilimler Dergisi, 2 (2), 11-18.

Dooley, Thomas Frank: 1971 "A Study of The Measurement of A Continuum of Alienation/ Integration In Terms of Its Five Alternate Meanings As These Are Related To Selected Sociological Factors", Marquette University, Master of Arts, 1-75.

Dönmezer, Sulhi: 1983 “Türk Toplumunda Sosyal Kontrol Aracı Olarak Ceza ve Ödüllendirme”, İstanbul Üniversitesi Hukuk Fakültesi Mecmuası, 48 (1-4), 295-315.

Dude, David Joseph: 2012 "Organizational Commitment of Principals: The Effects of Job Autonomy, Empowerment, and Distributive Justice", The University of Iowa, Doctoral Dissertation, 1-136.

Durand, Claude \& Tombelaine, Verdalee: 1975 “Employer Politics In Job Enrichment”, International Studies of Management \& Organization, 5 (3), 66-86.

Duru, Erdinç: 2008 "Yalnızlığı Yordamada Sosyal Destek ve Sosyal Bağlılığın Rolü”, Türk Psikoloji Dergisi, 23 (61), 15-24.

Duquette, David A.: 1993 “C J. Arthur On Marx and Hegel On Alienation”, Auslegung: A Journal of Philosophys, 19 (1), 75-85.

Efraty, David., Sirgy, M. Joseph \& Claiborne, C. B.: 1991 “The Effects of Personal Alienation On Organizational Identification: A Quality-of-Work-Life Model”, Journal of Business and Psychology, 6 (1), 57-78.

Ekman, Paul., Sorenson, E. Richard \& Friesen, Wallace V.: 1969 "Pan-Cultural Elements In Facial Displays of Emotion", New Series, 164 (3875), 86-88.

Ekman, Paul., Friesen, Wallace V \& Ellsworth, Phoebe: 1972 Emotion In The Human Face: Guidelines For Research and An Integration of Findings, Pergamon Press, 1-191.

Ekman, Paul: 2011 “What Is Meant By Calling Emotions Basic”, Emotion Review, 3 (4), 364-370.

Elma, Cevat: 2003 “İlköğretim Okulu Öğretmenlerinin İşe Yabancılaşması”, Ankara Üniversitesi Eğitim Bilimleri Enstitüsü, Doktora Tezi, 1-165.

Emmerik, IJ. Hetty Van., Euwema, Martin C \& Bakker, Arnold B.: 2007 “Threats of Workplace Violence and The Buffering Effect of Social Support", Group \& Organization Management, 32 (2), 152-175.

Engels, Friedrich: 1992 Ludwig Feuerbach ve Klasik Alman Felsefesinin Sonu, Çev. Sevim Belli, Sol Yayınları, 10-79.

Eren, Erol: 1978 “Örgütlerde Yönetime Katılma”, İstanbul Üniversitesi İşletme İktisadi Enstitüsü Dergisi, 2 (8), 13-28.

Ergil, Doğu: 1978 "Yabancılaşma Kuramına İlk Katkılar”, Ankara Üniversitesi Siyasal Bilgiler Fakültesi Dergisi, 33 (3), 93-108.

Erikson, Kai: 1986 "On Work and Alienation", American Sociological Review, 51 (1), 1-8.

Erjem, Yaşam: 2005 "Eğitimde Yabancılaşma Olgusu ve Öğretmen: Lise Öğretmenleri Üzerine 
Sosyolojik Bir Araştırma”, Türk Eğitim Bilimleri Dergisi, 3 (4), 395-417.

Eroğlu, Şeyma Gün: 2014 “Örgütlerde Duygusal Emek ve Tükenmişlik İlişkisi Üzerine Bir Araştırma”, Pamukkale Üniversitesi Sosyal Bilimler Enstitüsü, Doktora Tezi, 1-274.

Ertoy, Muhammet: 2013 “Türkiye’nin Modernleşme Sürecinde Din Eğitimi ve Yabancılaşma Sorunu”, Dokuz Eylül Üniversitesi Sosyal Bilimler Enstitüsü, Doktora Tezi, 1-235.

Esin, Pars: 1982 İş Bölümü, Yabancılaşma ve Sosyal Politika, Ankara Üniversitesi Siyasal Bilgiler Fakültesi Yayınları, No 502, 3-158.

Esser, I \& Olsen, K. M.: 2012 "Perceived Job Quality: Autonomy and Job Security Within A Multi - Level Framework", European Sociological Review, 28 (4), 443-454.

Fabes, Richard A \& Martin, Carol Lynn: 1991 "Gender and Age Stereotypes of Emotionally", Personality and Social Psychology Bulletin, 17 (5), 532-540.

Fatt, James Poon Teng: 2002 “Emotional Intelligence: For Human Resource Managers", Management Research News, 25 (11), 57-74.

Fazio, John., Gong, Baiyun., Sims, Randi \& Yurova, Yuliya: 2017 "The Role of Affective Commitment In The Relationship Between Social Support and Turnover Intention", Management Decision, 55 (3), 512-525.

Feierabend, Anja., Mahler, Philippe \& Staffelbach, Bruno: 2011 "Are There Spillover Effects of A Family Supportive Work Environment On Employees without Childcare Responsibilities?", Management Revue, 22 (2), 188-209.

Feuerbach, Ludwig: 1881 Essence of Christianity, Trübner \& Co., Ludgate Hill, 1-339.

Fildiş, Berna: 2016 “Bir Yöntem Olarak C. Wrıght Mills’in Toplumbilimsel Düşün’ünü Çözümlemek", The Journal of Academic Social Science Studies, Sayı 51, 139-156.

Fioto, Barbara: 2002 "Social Isolation: Important Construct In Community Health", Geriatric Nursing, 23 (1), 53-55.

Fisher, Cynthia D \& Ashkanasy, Neal M.: 2000 “The Emerging Role of Emotions In Work Life: An Introduction", Journal of Organizational Behavior, 21 (2), 123-129.

Frankl, Viktor E.: 2009 İnsanın Anlam Arayışı, Çev. Selçuk Budak, Okuyan Us Yayınları, 17-166. Fromm, Erich: 1955 The Sane Society, Routledge Classics, New York, 3-357.

Fromm, Erich: 1961 Marx’s Concept of Man, Frederick Ungar Publishing, 1-258.

Fromm, Erich: 1990 Umut Devrimi, Çev. Şemsa Yeğin, Payel Yayınları, 9-171.

Fromm, Erich: 1994 Kendini Savunan İnsan, Çev. Necla Arat, SAY Yayınları, 13-235.

Fromm, Erich: 1996 Özgürlükten Kaçış, Çev. Şemsa Yeğin, Payel Yayınları, 20-235.

Geçtan, Engin: 2016 Varoluş ve Psikiyatri, Metis Yayınları, 13-207.

Gemmill, Gary \& Oakley, Judith: 1992 “Leadership: An Alienating Social Myth?”, Human Relations, Cilt 45, Sayı 2, 113-129.

Geng, Zizhen., Liu, Chao., Liu, Xinmei \& Feng, Jie: 2014 “The Effects of Emotional Labor On Frontline Employee Creativity", International Journal of Contemporary Hospitality Management, 26 (7), 1046-1064.

Glomb, Theresa M \& Tews, Michael J.: 2004 "Emotional Labor: A Conceptualization and Scale Development", Journal of Vocational Behavior, Say1 64, 1-23.

Goldberg, Lewis R.: 1993 "The Structure of Phenotypic Personality Traits", American Psychologist, 48 (1), 26-34.

Goleman, Daniel: 2001 "An EI-Based Theory of Performance", The Emotionally Intelligent Workplace: How to Select For, Measure, and Improve Emotional Intelligence In Individuals, Groups, and Organizations, Ed. Cherniss, C ve Goleman, D., Jossey-Bass Publishers, 3-352.

Gopinath, R.: 2011 “Employees' Emotions In Workplace", Research Journal of Business Management, 5 (1).

Gök, Alihan \& Tekin, Nial: 2015 "Yabancılaşma ve Özsaygı: Çoğulcu Eleştiriler Üzerinden Bir Değerlendirme”, Marmara Üniversitesi Siyasal Bilimler Dergisi, 3(2), 279-301.

Göktürk, İsmail \& Günalan, Mustafa: 2006 "Modern ve Geleneksel Değerler Arasında Yaban- 
cılaşan İnsan", Selçuk Üniversitesi Karaman İktisadi ve İdari Bilimler Fakültesi Dergisi, 11 (9), 127-143.

Gracia, Eshter \& Ashkanasy, Neal M.: 2014 "Emotional Labor As A Dynamic Process In Service Organizations: Development of A Multi-Perspective", Multilevel Model, Emotions and The Organizational Fabric (Research On Emotion In Organizations), Sayı 10, 331-365.

Grandey, Alicia A.: 2000 "Emotion Regulation In The Workplace: A New Way To Conceptualize Emotional Labor", Journal of Occupational Health Psychology, 5 (1), 95-110.

Grandey, Alicia A.: 2003 "When The Show Must Go On: Surface Acting and Deep Acting As Determinants of Emotional Exhaustion and Peer - Rated Service Delivery", Academy of Management Journal, 46 (1), 86-96.

Grandey, Alicia A \& Diamond, Jennifer A.: 2010 "Interactions With The Public: Bridging Job Design and Emotional Labor Perspective", Journal of Organizational Behavior, 31 (2-3), 338-350.

Grandey, Alicia A \& Gabriel, Allison S.: 2015 "Emotional Labor At A Crossroads: Where Do We Go From Here?", The Annual Review of Organizational Psychology and Organizational Behavior, Sayı 2, 323-349.

Greenberg, Edward S \& Grunberg, Leon: 1995 "Work Alienation and Problem Alcohol Behavior", Journal of Health and Social Behavior, 36 (1), 83-102.

Greenberg, Leslie: 2006 "Emotion-Focused Therapy: A Synopsis", Journal of Contemporary Psychotherapy, 36 (2), 87-93.

Gross, James J.: 1998 “Antecedent-and Response-Focused Emotion Regulation: Divergent Consequences For Experience, Expression, and Physiology", Journal of Personality and Social Psychology, 74 (1), 224-237.

Groth, Markus., Hennig-Thurau, Thorsten \& Walsh, Gianfranco: 2009 “Customer Reactions To Emotional Labor: The Roles of Employee Acting Strategies and Customer Detection Accuracy", Academy of Management Journal, 52 (5), 958-974.

Gülaydın, Mustafa: 2019 "Algılanan Örgütsel Destek İle Duygusal Emek Davranışları Arasındaki İlișki Üzerine Bir Araştırma: Afyonkarahisar'daki Beş Yıldızlı Otel İșletmeleri Örneği”, Afyon Kocatepe Üniversitesi Sosyal Bilimler Enstitüsü, Yüksek Lisans Tezi, 1-187.

Güllüoğlu, Özlem: 2012 "Yerel Televizyon Çalışanlarının Örgütsel Stres Faktörleri: Kayseri İlinde Bir Araştırma”, İstanbul Üniversitesi İletişim Fakültesi Dergisi, Sayı 43, 77-104.

Gülova, Asena Altın., Palamutçuoğlu, Bedrettin Türker \& Palamutçuoğlu, Aynur Terzi: 2013 "Duygusal Emek İle İşe Bağlılık Arasındaki İşkide Amir Desteğinin Rolü: Üniversitede Öğrenci İşleri Personeline Yönelik Bir Araştırma”, Dokuz Eylül Üniversitesi İktisadi ve İdari Bilimler Fakültesi Dergisi, 28 (2), 41-74.

Gümüşeli, Ali İlker: 1994 "İzmir Ortaöğretim Okulları Yöneticilerinin Öğretmenler İle Aralarındaki Çatışmaları Yönetme Biçimleri”, Ankara Üniversitesi Sosyal Bilimler Enstitüsü, Doktora Tezi, 1-336.

Gümüştekin, Gülten Eren \& Gültekin, Fikret: 2009 "Stres Kaynaklarının Kariyer Yönetimine Etkileri”, Dumlupınar Üniversitesi Sosyal Bilimler Dergisi, Sayı 23, 147-158.

Halis, Mine \& Demirel, Yavuz:2016 "Sosyal Desteğin Örgütsel Soyutlama (Dışlanma) Üzerine Etkisi”, Kastamonu Üniversitesi İktisadi ve İdari Bilimler Fakültesi Dergisi, Sayı 11, 318-335.

Haslam, S. Alexander., O’Brien, Anne., Jetten, Jolanda., Vormedal, Karine \& Penna, Sally: 2005 "Taking The Strain: Social Identity, Social Support, and The Experience of Stress", British Journal of Social Psychology, Sayı 44, 355-370.

Heaney, Catherine A \& Israel, Barbara A: 2008 "Social Networks and Social Support", Health Behavior and Health Education: Theory, Research, and Practice, Ed. Glanz, K., Rimer, B. K ve Viswanath, K., Jossey-Bass, 3-552.

Helgeson, Vicki S \& Gottlieb, Benjamin H.: 2000 "Support Groups", Social Support Measurement and Intervention: A Guide For Health and Social Scientists, Ed. Cohen, S., Underwood, L. G ve Gottlieb, B. H., Oxford University Press, 3-345. 
Helsen, Marianne., Vollebergh, Wilma \& Meeus, Wim: 2000 "Social Support From Parents and Friends and Emotional Problems In Adolescence", Journal of Youth and Adolescence, 29 (3), 2000, 319 - 335.

Hirschfeld, Robert R \& Field, Hubert S.: 2000 “Work Centrality and Work Alienation: Distinct Aspects of A General Commitment To Work", Journal of Organizational Behavior, Say1 21, 789-800.

Hirschfeld, Robert R., Feild, Hubert S \& Bedelan, Arthur G.: 2000 "Work Alienation As An Individual-Difference Construct For Predicting Workplace Adjustment: A Test In Two Samples", Journal of Applied Social Psychology, 30 (9), 1880-1902.

Hochschild, Arlie Russell: 2003 The Managed Heart: Commercialization of Human Feelings, University of California Press, 3-307.

Horowitz, Irving Louis: 1966 “On Alienation and The Social Order", Philosophy and Phenomenological Research, 27 (2), 230-237.

House, James S.: 1981 Work Stress and Social Support, Addison-Wesley Publishing Company, $1-156$.

House, J. S., Umberson, D \& Landis, K. R.: 1988 "Structures and Processes of Social Support", Annual Review of Sociology, Sayı 14, 293-318.

Hudson, Wayne: 2005 “The Enlightenment Critique of Religion", Australian eJournal of Theology, $5(1), 1-12$.

Humphrey, Ronald H., Pollack, Jeffrey M \& Hawver, Thomas: 2008 "Leading With Emotional Labor", Journal of Managerial Psychology, 23 (2), 151-168.

Hur, Won Moo., Moon, Tae Won \& Jun, Jae Kyoon: 2013 “The Role of Perceived Organizational Support On Emotional Labor In The Airline Industry”, International Journal of Contemporary Hospitality Management, 25 (1), 105-123.

Hürmeriç, Pelin \& Baban, Ece: 2012 "Simmel, Veblen ve Sombart'ın Penceresinden Hedonik Tüketim: Ütopyada Negotium ve Otium”, Global Media Journal, 2 (4), 87-101.

Işı, Metin \& Hamurcu, Ali: 2017 "The Role of Job Stress At Emotional Labor's Effect On Intention To Leave: Evidence From Call Center Employees", Business and Economic Horizons, 13 (5), 652-665.

Izard, Carroll E.: 2007 "Basic Emotions, Natural Kinds, Emotion Schemas, and A New Paradigm”, Perspectives On Psychological Science, 2 (3), 260-280.

Izard, Carroll., Stark, Kevin., Trentacosta, Christopher \& Schultz, David: 2008 "Beyond Emotion Regulation: Emotion Utilization and Adaptive Functioning”, Child Development Perspectives, 2 (3), 156-163.

İlhan, Nilüfer: 2012 "Yabancılaşma Olgusu ve Kürk Mantolu Madonna Romanı", Uluslararası Sosyal Araştırmalar Dergisi, 5 (20), 41-59.

İyigün, N. Öykü \& Çetin, Canan: 2012 "Psikolojik Kontratın Örgütsel Sapma Üzerindeki Etkisi ve İlaç Sektöründe Bir Araştırma”, Öneri Dergisi, 10 (37), 15-29.

Jackson, Susan E.: 1983 "Participation In Decision Making As A Strategy For Reducing Job -Related Strain", Journal of Applied Psychology, 68 (1), 3-19.

Johnson, Frank: 1963 “Psychological Alienation: Isolation and Self-Estrangement”, Psychoanalytic Review, 62 (3), 369-405.

Johnson, Hazel Anne M.: 2004 "The Story Behind Service With A Smile: The Effects of Emotional Labor On Job Satisfaction, Emotional Exhaustion, and Affective Well-Being", University of South Florida, Graduate Theses and Dissertations, 1-76.

Johnson, Hazel Anne M \& Spector, Paul E.: 2007 "Service With A Smile: Do Emotional Intelligence, Gender, and Autonomy Moderate The Emotional Labor Process?", Journal of Occupational Health Psychology, 12 (4), 319-333.

Jones, Lyndon: 1977 “Employee Motivation Through Job Enrichment”, Education and Training, 
19 (7), 215-219.

Ju, Chengting., Lan, Jijun., Li, Yuan., Feng, Wei \& You, Xuqun: 2015 “The Mediating Role of Workplace Social Support On The Relationship Between Trait Emotional Intelligence and Teacher Burnout", Teaching and Teacher Education, Sayı 51, 58-67.

Kain, Philip J.: 1993 “Marx, Housework, and Alienation”, Hypatia, 8 (1), 121-144.

Kammeyer-Mueller, John D., Rubenstein, Alex L., Long, David M., Odio, Michael A., Buckman, Brooke R., Zhang, Yiwen \& Halvorsen-Ganepola, Marie D. K.: 2013 "A Meta-Analytic Structural Model of Dispositonal Affectivity and Emotional Labor”, Personnel Psychology, Say1 66, 47-90.

Kaner, Sema: 2003 “Aile Destek Ölçeği: Faktör Yapısı, Güvenirlik ve Geçerlik Çalışmaları”, Ankara Üniversitesi Eğitim Bilimleri Fakültesi Özel Eğitim Dergisi, 4 (1), 57-72.

Kanungo, Rabindra N.: 1992 "Alienation and Empowerment: Some Ethical Imperatives In Business", Journal of Business Ethics, Sayı 11, 413-422.

Kaplan, Robert M., Patterson, Thomas L., Kerner, David., Grant, Igor \& HIV Neurobehavioral Research Center: 1997 "Social. Support: Cause or Consequence of Poor Health Outcomes In Men With HIV Infection?", Sourcebook of Social Support and Personality, Ed. Gregory R. Pierce, Brian Lakey, Irwin G. Sarason, Barbara R. Sarason, Plenum Press, 3-508.

Kart, Elife: 2011 "Bir Duygu Yönetimi Süreci Olarak Duygusal Emeğin Çalışanlar Üzerindeki Etkisi”, Çalı̧̧ma ve Toplum, 30 (3), 215-230.

Kaur, Kamalpreet: 2014 "Alienation Among College Students of Jammu and Kashmir In Relation To Their Emotional Maturity and Home Environment", International Journal of Research In Education Methodology, 5 (1), 551-557.

Kaur, Jasbir \& Singh, Gurmit: 2015 "Alienation Among Urban Adolescents In Relation To Emotional Intelligence", International Journal of Allied Practice, Research and Review, 2 (1), 32-36.

Kaya, Mahmut: 2012 “Klasik Sosyolojik Perspektifte Modernleşme Tartışmaları”, Birey ve Toplum Dergisi, 2 (4), 111-132.

Kaya, Ufuk \& Serçeoğlu, Neslihan: 2013 "Duygu İşçilerinde İşe Yabancılaşma: Hizmet Sektöründe Bir Araştırma”, Çalışma ve Toplum, 1 (36), 311-346.

Kaymaz, Kurtuluș: 2010 "The Effects of Job Rotation Practices On Motivation: A Research On Managers In The Automotive Organizations", Business and Economics Research Journal, 1 (3), 69-86.

Keen, Suzanne: 2007 Empathy and The Novel, Oxford University Press, 3-242.

Kewalramani, Soni., Agrawal, Manju \& Rastogi, Mukta Rani: 2015 "Models of Emotional Intelligence: Similarities and Discrepancies”, Indian Journal of Positive Psychology, 6 (2), 178-181.

Khorshid, Leyla \& Arslan, Gülşah Gürol: 2006 "Hemşirelik ve Sosyal Desteğin Önemi”, Dirim, Sayı 1, 182-188.

Kılıçaslan, Eyüp Ali: 2016 “Hegel'in Tinin Görüngübilimi’nde Kendine-Yabancılaşmış Tinin Dünyası Olarak Kültür Dünyasının Diyalektiği Ya Da Marx’ in 1844 El Yazmaları’ndaki Eleştirilerine Karşı Bir Hegel Savunusu Denemesi”, ViraVerita E-Dergi, Sayı 4, 1-36.

Kiffin-Petersen, Sandra A., Jordan, Catherine L \& Soutar, Geoffrey N.: 2011 “The Big Five, Emotional Exhaustion and Citizenship Behaviors In Service Settings: The Mediating Role of Emotional Labor", Personality and Individual Differences, Sayı 50, 43-48.

Kim, Hyun Jeong: 2008 "Hotel Service Providers' Emotional Labor: The Antecedents and Effects On Burnout", International Journal of Hospitality Management, Say1 27, 151-161.

Kim, Taegoo Terry., Yoo, Joanne Jung Eun., Lee, Gyehee \& Kim, Joungman: 2012 "Emotional Intelligence and Emotional Labor Acting Strategies Among Frontline Hotel Employees”, International Journal of Contemporary Hospitality Management, 24 (7), 1029-1046.

Kim, Hyun Jeong., Hur, Won Moo., Moon, Tae Won \& Jun, Jea Kyoon: 2017 "Is All Support Equal? The Moderating Effects of Supervisor, Coworker, and Organizational Support On 
The Link Between Emotional Labor and Job Performance", Business Research Quarterly, 20 (2), 124-136.

Kiraz, Sibel: 2012 "Hegel Felsefesinde Yabancılaşmanın Rolü ve Anlamı”, Kutadgubilig Felsefe-Bilim Araştırmaları Dergisi, Sayı 21, 1-29.

Kitamura, Toshinori., Kijima, Nobuhiko., Watanabe, Kyoko., Takezakii, Yoshie \& Tanaka, Eriko: 1999 "Precedents of Perceived Social Support: Personality and Early Life Experiences", Psychiatry and Clinical Neurosciences, Cilt 53, 649-654.

Knowles, William H.: 1956 “The Sane Society By Erich Fromm”, Journal of Political Economy, 64 (6), 543-544.

Koçel, Tamer: 2011 İşletme Yöneticiliği, Beta Yayınevi, 13. Baskı, 5- 691.

Kohn, Melvin L.: 1976 “Occupational Structure and Alienation”, American Journal of Sociology, 82 (1), 111-130.

Kong, Feng., Zhao, Jingjing \& You, Xuqun: 2012 "Emotional Intelligence and Life Satisfaction In Chinese University Students: The Mediating Role of Self - Esteem and Social Support", Personality and Individual Differences, 53 (8), 1039-1043.

Korkmaz, Oya \& Aydemir, Sibel: 2015 "A Research For The Determination of The Relationship Between Organizational Conflict Management and Organizational Alienation", International Review of Management and Marketing, 5 (4), 230-241.

Korman, Abraham K., Wittig-Berman, Ursula \& Lang, Dorothy: 1981 "Career Success and Personal Failure: Alienation In Professionals and Managers", Academy of Management Journal, 24 (2), 342-360.

Kökden, Funda Çivit \& Işık, Murşit: 2018 “Çalışma Hayatında Duygusal Emek ve İşe Yabancılaşma İlişkisi: Banka Çalışanları Üzerine Bir Uygulama”, Süleyman Demirel Üniversitesi İktisadi ve İdari Bilimler Fakültesi Dergisi, 23 (4), 1215-1237.

Köksel, Lale: 2009 “İş Yaşamında Duygusal Emek ve Ampirik Bir Çalışma”, Celal Bayar Üniversitesi Sosyal Bilimler Enstitüsü, Yüksek Lisans Tezi, 1-100.

Köse, Gizem: 2019 “Duygusal Emek Faktörünün Hizmet Kalitesi ve İşe Yabancılaşma Üzerindeki Etkisi”, Marmara Üniversitesi Sosyal Bilimler Enstitüsü, Yüksek Lisans Tezi, 1-158.

Krause, Neal \& Borawski-Clark, Elaine: 1994 "Clarifying The Functions of Social Support In Later Life", Research On Aging, 16 (3), 251-279.

Kruml, Susan M \& Geddes, Deanna: 2000 "Exploring The Dimensions of Emotional Labor: The Heart of Hochschild's Work", Management Communication Quarterly, 14 (1), 8-49.

Kurt, Zeylan: 2013 “Duygusal Emek Faktörünün Yabancılaşmaya Etkisi: İstanbul'daki Otel İşletmeleri ve Seyehat Acentalarına Yönelik Bir Araştırma”, Çanakkale Onsekiz Mart Üniversitesi, Sosyal Bilimler Enstitüsü, Yüksek Lisans Tezi, 1-66.

Kurtulmuş, Mehmet \& Yiğit, Bilgin: 2016 "İşe Yabancılaşmanın Öğretmenlerin İşten Ayrılma Niyetine Etkisi”, Mersin Üniversitesi Eğitim Fakültesi Dergisi, 12 (3), 860-871.

Kurtz, Paul W.: 1956 “The Sane Society By Erich Fromm”, Ethics, 66 (4), 289-292.

Langford, Catherine Penny Hinson., Bowsher, Juanita., Maloney, Joseph P \& Lillis, Patricia P.: 1997 "Social Support: A Conceptual Analysis", Journal of Advanced Nursing, Sayı 25, 95100.

Lazanyi, Kornélia: 2010 “Emotional Labour and Its Consequences In Health-Care Setting”, Fiatal Kutatók Szimpóziuma, Macaristan, 149-156.

Lazányi, Kornélia: 2011 “Organizational Consequences of Emotional Labour In Mangenent”, Applied Studies In Agribusiness and Commerce, Sayı 5, 125-130.

Lazarus, Richard S.: 1991 Emotion and Adaptation, Oxford University Press, 3-557.

Lee, Hyuneung: 2010 "The Relationship Between Emotional Intelligence and Emotional Labor and Its Effect On Job Burnout In Korean Organizations", The University of Minnesota, Doctoral Dissertation, 1-168.

Lee, De Chih., Hung, Li Mei \& Huang, Shou Chi: 2012 “Does Job Enjoyment and Organizational Support Affect Emotional Labor?”, Journal of Business Research-Türk, 4 (2), 5-29. 
Lee, Ye Hoon \& Chelladurai, Packianathan:2016 "Affectivity, Emotional Labor, Emotional Exhaustion, and Emotional Intelligence In Coaching", Journal of Applied Sport Psychology, Say1 28, 170-184.

Leibovich, N., Schmid, V \& Calero, A.: 2018 “The Need To Belong (NB) In Adolescence: Adaptation of A Scale For Its Assessment", Psychology and Behavioral Science, 8 (5), 1-7.

Lin, Nan: 1986 "Conceptualizing Social Support", Social Support, Life Events, and Depression, Ed. Nan Lin, Alfred Dean, Walter M. Ensel, Academic Press, 1-377.

Linz, Sheila J

\& Sturm, Bonnie A.: 2013 “The Phenomenon of Social Isolation In The Severely Mentally Ill”, Perspectives In Psychiatric Care, Cilt 49, 243-254.

Liu, Yongmei: 2006 "The Antecedents and Consequences of Emotion Regulation At Work", The Florida State University, Doctoral Dissertation, 1-146.

Ludz, Peter C.: 1976 "Alienation As A Concept In The Social Sciences", Theories of Alienation, Ed. Geyer, R.F ve Schweitzer, D.R., Springer, 3-265.

Lumpkin, G. T \& Dess, Gregory G.: 1996 “Clarifying The Entrepreneurial Orientation Cunstruct and Linking It To Performance", Academy of Management Review, 21 (1), 135-172.

Macaleer, William D \& Shannon, Jones B.: 2002 "Emotional Intelligence: How Does It Affect Leadership?”, Employment Relations Today, 9-19.

Maccoby, Michael: 1984 "Helping Labor and Management Set Up A Quality-of-Worklife Program”, Monthly Labor Review, 107 (3), 28-32.

Mann, Sandi: 1997 “Emotional Labour In Organizations”, Leadership \& Organization Development Journal, 18 (1), 4-12.

Mann, Sandi: 2007 "Expectations of Emotional Display In The Workplace: An American/British Comparative Study", Leadership \& Organization Development Journal, 28 (6), 552-570.

Marcuse, Herbert: 1980 "Protosocialism and Late Capitalism: Toward A Theoretical Synthesis Based On Bahro's Analysis”, International Journal of Politics, 10 (2-3), 25-48.

Marcuse, Herbert: 1964 One-Dimensional Man, Routledge \& Kegan Paul, 3-275.

Marks, Karl: 19761844 El Yazmaları Ekonomi Politik ve Felsefe, Çev. Kenan Somer, Sol Yayınlar1, 9-157.

Marshall, Greg W., Michaels, Charles E \& Mulki, Jay P.: 2007 "Workplace Isolation: Exploring The Construct and Its Measurement”, Psychology \& Marketing, 24 (3), 195-223.

Marx, Karl \& Engels, Frederick: 1988 Economic And Philosophic Manuscripts of 1844 and The Communist Manifesto, Çev. Martin Milligan, Prometheus Books, 9-243.

Mayer, John D \& Salovey, Peter: 1993 “The Intelligence of Emotional Intelligence”, Intelligence, Say1 17, 433-442.

Mayer, John D \& Salovey, Peter: 1997 “What Is Emotional Intelligence?", Emotional Development and Emotional Intelligence, Ed. Salovey, P ve Sluyter, D. J., Basic Books, 3-288.

Mayer, John D., Salovey, Peter., Caruso, David R \& Cherkasskiy, Lillia: 2011 "Emotional Intelligence", The Cambridge Handbook of Intelligence, Ed. Sternberg, R. J ve Kaufman, S. B., Cambridge University Press, 3-984.

McClosky, Herbert \& Schaar, John H.: 1965 "Psychological Dimensions of Anomy”, American Sociological Review, 30 (1), 14-40.

McGene, Juliana: 2013 "Social Fitness and Resilience: A Review of Relevant Constructs, Measures, and Links to Well-Being", RAND Corporation, 1-47.

Mcszaros, Istvan: 1970 Marx's Theory of Alienation, Merlin Press, London, 9-351.

Mehta, Sandhya \& Singh, Namrata: 2013 "A Review Paper On Emotional Intelligence: Models and Relationship With Other Constructs", International Journal of Management \& Information Technology, 4 (3), 343-352.

Meissner, W. W.: 1974 “Alienation: Context and Complications", Journal of Religion and Health, 
$13(1), 23-39$.

Mengenci, Cengiz: 2015 “İş Tatmini, Duygusal Emek ve Tükenmişlik İlişkilerinin Belirlenmesi”, Ege Akademik Bakış, 15 (1), 127-139.

Merton, Robert K.: 1968 Social Theory and Social Structure, The Free Press, 1-698.

Mesmer-Magnus, Jessica R., DeChurch, Leslie A \& Wax, Amy: 2012 "Moving Emotional Labor Beyond Surface and Deep Acting: A Discordance-Congruence Perspective”, Organizational Psychology Review, 2 (1), 6-53.

Metaj-Macula, Albulena: 2017 "Emotional Intelligence, Its Relation With Social Interaction and Perceived Social Support", European Journal of Social Sciences Education and Research, 4 (4), 57-63.

Mikeska, Jessica., Hamwi, G. Alexander., Friend, Scott B., Rutherford, Brian N \& Park, Jungkun: 2015 "Artifical Emotions Among Salespeople: Understanding The Impact of Surface Acting", The Marketing Management Journal, 25 (2), 54-70.

Mikolajczak, Moira., Menil, Clementine \& Luminet, Olivier: 2007 "Explaining The Protective Effect of Trait Emotional Intelligence Regarding Occupational Stress: Exploration of Emotional Labour Processes", Journal of Research In Personality, Say1 41, 1107-1117.

Miller, George A.: 1967 "Professionals In Bureaucracy: Alienation Among Industrial Scientists and Engineers", American Sociological Review, 32 (5), 755-768.

Miller, John: 1973 "Schooling and Self-Alienation: A Conceptual View", The Journal of Educational Thought (JET), 7 (2), 105-120.

Miller, Arlene Michaels., Sorokin, Olga., Wang, Edward., Feetham, Suzanne., Choi, Michelle \& Wilbur, JoEllen: 2006 "Acculturation, Social Alienation, and Depressed Mood In Midlife Women From The Former Soviet Union", Research In Nursing \& Health, Sayı 29, 134-146.

Mills, C. Wright: 2000 The Sociological Imagination, Oxford University Press, 3-248.

Mills, C. Wright: 2007 Toplumbilimsel Düşün, Çev. Ünsal Oskay, Der Yayınları, 11-374.

Mishra, Sushanta K: 2011 "Sales Employee's Emotional Labor: A Question of Image or Support", What Have We Learned? Ten Years On, Ed. Härtel, C. E. J., Ashkanasy, N. M ve Zerbe, W. J., Emerald Group Publishing Limited, 1-363.

Modassir, Atika \& Singh, Tripti: 2008 "Relationship of Emotional Intelligence With Transformational Leadership and Organizational Citizenship Behavior", International Journal of Leadershıp Studies, 4 (1), 3-21.

Monaghan, Diane M.: 2006 "Emotional Labor In Customer Service Work: The Perceived Difficulty and Dispositional Antecedents", University of Akron, Doctoral Disertation, 1-129.

Morris, J. Andrew \& Feldman, Daniel C.: 1996 “The Dimensions, Antecedents, and Consequences of Emotional Labor", Academy of Management Review, 21 (4), 986-1010.

Morris, J. Andrew \& Feldman, Daniel C.: 1997 “Managing Emotions In The Workplace”, Journal of Managerial Issues, 257-274.

Mottaz, Clifford J.: 1981 “Some Determinants of Work Alienation”, The Sociological Quarterly, $22(4), 515-529$.

Mumcu, Artur Yetvart \& Eser, Gül: 2017 “Duygusal Emek Öncel ve Sonuçları: Lisansüstü Tezleri Üzerinde Bir İnceleme”, 5. Örgütsel Davranış Kongresi Bildiri Kitabı.

Nair, Nisha \& Vohra, Neharika: 2010 "An Exploration of Factors Predicting Work Alienation of Knowledge Workers", Management Decision, 48 (4), 600-615.

Naktiyok, Atılhan \& Gürsoy, Ali: 2014 "Yenilik Yönetim Performansı ve Duygusal Zekâ Yeteneği”, Uluslararası Sosyal Araştırmalar Dergisi, 7 (35), 712-729.

Neal, Arthur G \& Seeman, Melvin: 1964 "Organizations and Powerlessness: A Test of The Mediation Hypothesis", American Sociological Review, 29 (2), 216-226.

Nettler, Gwynne: 1956 “The Sane Society By Erich Fromm”, American Journal of Sociology, 61 (6), 644-646.

Neves, Pedro \& Eisenberger, Robert: 2014 "Perceived Organizational Support and Risk Taking”, 
Journal of Managerial Psychology, 29 (2), 187-205.

Nixon, Ashley E., Yang, Liu Qin., Spector, Paul E \& Zhang, Xichao: 2011 "Emotional Labor In China: Do Perceived Organizational Support and Gender Moderate The Process?", Stress and Health, 27 (4), 289-305.

Oğuz, Hatice \& Özkul, Metin: 2016 “Duygusal Emek Sürecine Yön Veren Sosyolojik Faktörler Üzerine Bir Araştırma: Batı Akdeniz Uygulaması”, Süleyman Demirel Üniversitesi Vizyoner Dergisi, 7 (16), 130-154.

Oktuğ, Zeynep: 2013 "Algılanan Örgütsel Destek İle Duygusal Emek Davranışları Arasındaki İlişkide Algılanan Örgütsel Prestijin Biçimlendirici Etkisi”, Elektronik Sosyal Bilimler Dergisi, 12 (46), 370-381.

Olsen, Marvin E.: 1965 "Alienation and Political Opinions", The Public Opinion Quarterly, 29 (2), 200-2012.

Oral, Lale \& Köse, Sevinç: 2011 "Hekimlerin Duygusal Emek Kullanımı İle İş Doyumu ve Tükenmişlik Düzeyleri Arasındaki İliş̧kiler Üzerine Bir Araştırma”, Süleyman Demirel Üniversitesi İktisadi ve İdari Bilimler Fakültesi Dergisi, 16 (2), 463-492.

Organ, Dennis W.: 1990 “The Motivational Basis of Organizational Citizenship Behavior”, Research In Organizational Behavior, Cilt 12, 43-72.

Ortmeyer, Dale H.: 1998 “Revisiting Erich Fromm”, International Forum of Psychoanalysis, 7 (1), 25-33.

O'Sullivan, Maureen., Guilford, J. P \& deMille, R.: 1965 ”The Measurement of Social Intelligence", ERIC Report Resume, Sayı 34, 3-43.

Otto, Luther B \& Featherman, David L.: 1975 "Social Structural and Psychological Antecedents of Self - Estrangement and Powerlessness”, American Sociological Review, 40 (6), 701-719.

Öcal, Kubilay \& Şenel, Ender: 2016 "Duygusal Zekânın Sosyal Destek Algısı Üzerindeki Etkisi: Öz Yeterlik İnancının Aracı Rolü”, Sosyal ve Beşeri Bilimler Araştırmaları Dergisi, 17 (36), 138-154.

Öngöre, Özgür: 2016 "Çalışma Yaşamında Duygusal Emeğin Yeri ve Değeri Üzerine Kuramsal Bir Çalışma”, Atatürk Üniversitesi İktisadi ve İdari Bilimler Dergisi, 30 (5), 1161-1177.

Özdevecioğlu, Mahmut: 2004 "Sosyal Destek ve Yaşam Tatmininin Mesleki Stres Üzerindeki Etkileri: Kayseri'de Faaliyet Gösteren İşletme Sahipleri İle Bir Araştırma”, Hacettepe Üniversitesi İktisadi ve İdari Bilimler Fakültesi Dergisi, 22 (1), 209-233.

Özdevecioğlu, Mahmut: 2004 "Duygusal Olaylar Teorisi Çerçevesinde Pozitif ve Negatif Duygusallığın Algılanan Örgütsel Adalet Üzerindeki Etkilerini Belirlemeye Yönelik Bir Araştırma”, Ankara Üniversitesi Siyasal Bilgiler Fakültesi, 59 (3), 181-202.

Özkalp, Enver., Arıcı, Hüsnü., Bayraktar, Rüveyde., Aydın, Orhan., Erkal, Buket \& Uzunöz, Ali: 2004 "Davranı̧̧ Bilimlerine Giriş”, Anadolu Üniversitesi Açıköğretim Fakültesi Yayını, Sayı $1355,1-301$.

Özkan, Gülden: 2013 “Çağrı Merkezlerinde Duygusal Emek ve Örgütsel İletişim”, Selçuk İletişim Dergisi, 7 (4), 64-80.

Özyurt, Cevat: 2007 “Durkheim Sosyolojisinde Ahlâkî Kontrol Sorunu”, Değerler Eğitimi Dergisi, 5 (13), 95-120.

Parker, Henry: 2006 Stress Management, Global Media, 4-108.

Payne, Thomas J., Andrew, Michael., Butler, Kenneth R., Wyatt, Sharon B., Dubbert, Patricia M \& Mosley, Thomas H.: 2012 "Psychometric Evaluation of The Interpersonal Support Evaluation List-Short Form In The ARIC Studc Cohort", SAGE Open, 2 (3), 1-8.

Pearlin, Leonard I.: 1962 "Alienation From Work: A Study of Nursing Personnel", American Sociological Review, 27 (3), 314-326.

Peart, Frances M., Roan, Amanda M \& Ashkanasy, Neal M.: 2012 "Trading In Emotions: A Closer Examination of Emotional Labor", Experiencing and Managing Emotions In The Workplace, Ed. Ashkanasy, N. M., Härtel, C. E. J ve Zerbe, W. J, Emerald Group Publishing 
Limited, Bingley, 1-401.

Pehlivan, İnayet: 1990 “Örgütün Davranışsal Sorunlarını Azaltma Yaklaşımları”, Ankara Üniversitesi Eğitim Bilimleri Fakültesi Dergisi, 23 (1), 163-173.

Petrovic, Gajo: 1963 "Marx's Theory of Alienation", Philosophy and Phenomenological Research, 23 (3), 419-426.

Pettinger, Richard: 2002 Stress Management, Capstone Publishing, 1-124.

Polatçı, Sema: 2015 “Örgütsel ve Sosyal Destek Algılarının Yaşam Tatmini Üzerindeki Etkisi: İş ve Evlilik Tatmininin Aracılık Rolü”, Ekonomik ve Sosyal Araştırmalar Dergisi, 11 (2), 25-44.

Polatc1, Sema \& Özyer, Kubilay: 2015 “Duygusal Emek Stratejilerinin Duygusal Zekanın Tükenmişliğe Etkisindeki Aracılık Rolü”, Abant İzeet Baysal Üniversitesi Sosyal Bilimler Enstitüsü Dergisi, 15 (3), 131-156.

Pontuso, James F.: 2015 “Marx's Concept of Alienation: With A Brief Assessment”, Philosophy Study, 5 (1), 1-15.

Prati, L. Melita., Liu, Yongmei., Perrewé, Pamela L \& Ferris, Gerald R.: 2009 "Emotional Intelligence As Moderator of The Surface Acting-Strain Relationship”, Journal of Leadership \& Organizational Studies, 15 (4), 368-380.

Procidano, Mary E \& Heller, Kenneth: 1983 "Measures of Perceived Social Support From Friends and From Family: Three Validation Studies", American Journal of Community Psychology, 11 (1), 1-24.

Rae, Gavin: 2012 "Hegel, Alienation, and The Phenomenological Development of Consciousnesss", International Journal of Philosophical Studies, 20 (1), 23-42.

Rafaeli, Anat \& Sutton, Robert I.: 1987 "Expression of Emotion As Part of The Work Role", The Academy of Management Review, 12 (1), 23-37.

Ramachandran, Yashotha., Jordan, Peter J., Troth, Ashlea C \& Lawrence, Sandra A.: 2011 "Emotional Intelligence, Emotional Labour and Organisational Citizenship Behaviour In Service Environments", International Journal of Work Organisation and Emotion, 4 (2), 136-157.

Rasmussen, Brian \& Salhani, Daniel: 2008 "Resurrecting Erich Fromm”, Smith College Studies In Social Work, 78 (2-3), 201-225.

Ratner, Carl: 2000 "A Cultural-Psychological Analysis of Emotions", Culture \& Psychology, 6 (1), 5-39.

Ritzer, George: 2010 Sociological Theory, McGraw-Hill, New York, 1-664.

Roberts, Robert C.: 1988 “What An Emotion Is: A Sketch”, The Philosophical Review, 97 (2), 183-209.

Robbins, Stephen P \& Coulter, Mary: 2010 Management, Pearson, 2-643.

Rosenberg, Morris: 1965 Society and The Adolescent Self-Image, Princeton University Press, 3-326.

Rosenberg, Morris., Schooler, Carmi., Schoenbach, Carrie \& Rosenberg, Florence: 1995 “Global Self-Esteem and Specific Self-Esteem”, American Sociological Review, 60 (1), 141-156.

Rosenfeld, Lawrence B \& Richman, Jack M.: 1997 "Developing Effective Social Support: Team Building and The Social Support Process", Journal of Applied Sport Psychology, 9 (1), 133153.

Ross, Catherine E \& Mirowsky, John: 1987 "Normlessness, Powerlessness, and Trouble With The Law", Criminology, 25 (2), 257-278.

Ross, Catherine E.: 2011 “Collective Threat, Trust, and The Sense of Personal Control”, Journal of Health and Social Behavior, 52 (3), 287-296.

Rotenstreich, Nathan: 1963 "On The Ecstatic Sources of The Concept of Alienation", The Review of Metaphysics, 16 (3), 550-555.

Rovai, Alfred P \& Wighting, Mervyn J.: 2005 "Feelings of Alienation and Community Among Higher Education Students In A Virtual Classroom”, The Internet and Higher Education, 
Say1 8, 97-110.

Ruiz-Junco, Natalia: 2015 "Stranger To You and Stranger To Myself? Theorizing Self - Estrangement", The Diversity of Social Theories, Cilt 29, 147-168.

Sadullah, Ömer., Uyargil, Cavide., Acar, Ahmet Cevat., Özçelik, A. Oya., Dündar, Gönen., Ataay, İsmail Durak., Adal, Zeki \& Tüzüner, Lale: 2013 İnsan Kaynakları Yönetimi, Beta Yay1nevi, 1-713.

Salovey, Peter \& Mayer, John D.: 1990 "Emotional Intelligence", Imagination, Cognition and Personality, 9 (3), 185-211.

San, Coşkun: 2003 "Yabancılaştırma-Yabancılaşma”, Amme İdaresi Dergisi, 36 (3), 1-7.

Sanchez, Juan I., Korbin, William P \& Viscarra, Diana M.: 1995 "Corporate Support In The Aftermath of A Natural Disaster: Effects On Employee Strains", The Academy of Management Journal, 38 (2), 504-521.

Sarason, Irwin G., Levine, Henry M., Basham, Robert B \& Sarason, Barbara R.: 1983 "Assessing Social Support: The Social Support Questionnaire", Journal of Personality and Social Psychology, 44 (1), 127-139.

Sarros, J. C., Tanewski, G. A., Winter, R. P., Santora, J. C \& Densten, I. L.: 2002 “Work Alienation and Organizational Leadership", British Journal of Management, Say1 13, 285-304.

Sayers, Sean: 2003 "Creative Activity and Alienation In Hegel and Marx", Historical Materialism, 11 (1), 107-128.

Schaefer, Catherine., Coyne, James C \& Lazarus, Richard S.: 1981 “The Health-Related Functions of Social Support", Journal of Behavioral Medicine, 4 (4), 381-406.

Schaubroeck, John \& Jones, James R.: 2000 "Antecedents of Workplace Emotional Labor Dimensions and Moderators of Their Effects On Physical Symptoms", Journal of Organizational Behavior, 21 (2), 163-183.

Schimek, Jean G \& Meyer, Roslyn Milstein: 1975 "Dimensions of Alienation and Pathology", Psychological Reports, Sayı 37, 727-732.

Scott, Brent A \& Barnes, Christopher M.: 2011 "A Multilevel Field Investigation of Emotional Labor, Affect, Work Withdrawal, and Gender", The Academy of Management Journal, 54 (1), 116-136.

Scott, Brent A., Barnes, Christopher M \& Wagner, David T.: 2012 "Chameleonic Or Consistent? A Multilevel Investıgation of Emotional Labor Variability and Self-Monitoring", Academy of Management Journal, 55 (4), 905-926.

Seçer, H. Şebnem: 2010 "Çalışma Yaşamında Duygular ve Duygusal Emek: Sosyoloji, Psikoloji ve Örgüt Teorisi Açısından Bir Değerlendirme”, Sosyal Siyaset Konferansları Dergisi, Sayı 50, 81-834.

Seeman, Melvin: 1959 “On The Meaning of Alienation”, American Sociological Review, 24 (6), 783-791.

Seeman, Melvin \& Evans, John W.: 1962 "Alienation and Learning In A Hospital Setting", American Sociological Review, 27 (6), 772-782.

Seeman, Melvin: 1966 "Alienation, Membership, and Political Knowledge: A Comparative Study”, The Public Opinion Quarterly, 30 (3), 353-367.

Seeman, Melvin: 1967 “On The Personal Consequences of Alienation In Work", American Sociological Review, 32 (2), 273-285.

Seeman, Melvin: 1967 "Powerlessness and Knowledge, A Comparative Study of Alienation and Learning", Sociometry, 30 (2), 105-123.

Seeman, Melvin: 1983 "Alienation Motifs In Contemporary Theorizing: The Hidden Continuity of the Classic Themes", Social Psychology Quarterly, 46 (3), 171-184.

Seery, Brenda L \& Corrigall, Elizabeth A.: 2009 "Emotional Labor: Links To Work Attitudes and Emotional Exhaustion", Journal of Managerial Psychology, 24 (8), 797-813.

Sen, Suvarna: 2008 "Interpersonal Skills Through Emotional Intelligence: A Psychological Pers- 
pective", The Icfai University Journal of Soft Skills, 2 (4), 25-30.

Shantz, Amanda., Alfes, Kerstin., Bailey, Catherie \& Soane, Emma: 2015 "Drivers and Outcomes of Work Alienation: Reviving A Concept", Journal of Management Inquiry, 24 (4), 283-393.

Shepard, Jon M.: 1971 Automation and Alienation: A Study of Office and Factory Workers, The MIT Press, 1-163.

Sherbourne, Cathy Donald \& Stewart, Anita L.: 1991 “The Mos Social Support Survey”, Social Science \& Medicine, 32 (6), 705-714.

Shrivastava, Anupama \& Mukhopadhyay, Anjana: 2009 "Alienation and Emotional Intelligence of Adolescents With Internalising Symptoms", Journal of the Indian Academy of Applied Psychology, 35 (1), 99-106.

Siedlecki, Karen L., Salthouse, Timothy A.,, Oishi, Shigehiro \& Jeswani, Sheena: 2014 "The Relationship Between Social Support and Subjective Well-Being Across Age", Social Indicators Research, 117 (2), 561-576.

Simmel, Georg: 2000 “Metropol ve Zihinsel Yaşam”, Şehir ve Cemiyet, Çev. Ahmet Aydoğan, İz Yayıncilık, 7-222.

Simmel, Georg: 2003 Modern Kültürde Çatışma, Çev. Tanıl Bora, Nazile Kalaycı ve Elçin Gen, İletişim Yayınları, 9-135.

Simmel, Georg: 2009 Bireysellik ve Kültür, Çev. Tuncay Birkan, Metis Yayınları, 9-364.

Singh, Kavita: 2008 "Emotional Intelligence \& Work Place Effectiveness", The Indian Journal of Industrial Relations, 44 (2), 292-302.

Singh, Gurmit: 2015 "Alienation Among B. Ed. Students In Relation To Self - Efficacy and Emotional Intelligence", International Education \& Research Journal, 1 (5), 69-71.

Slattery, Martin: 2008 Sosyolojide Temel Fikirler, Çev. Özlem Balkız, Gülhan Demiriz, Hacer Harlak, Cevdet Özdemir, Şebnem Özkan, Ümit Tatlıcan, Sentez Yayıncılık, 7-528.

Sliter, Michael., Chen, Yiwei., Withrow, Scott \& Sliter, Katherine: 2013 "Older and (Emotionally) Smarter? Emotional Intelligence As A Mediator In The Relationship Between Age and Emotional Labor Strategies In Service Employees", Experimental Aging Research, 39 (4), 466-479.

Sloan, Melissa M.: 2014 "The Consequences of Emotional Labor For Public Sector Workers and The Mitigating Role of Self-Efficacy”, American Review of Public Administration, 44 (3), 274-290.

Soltis, Scott M., Agneessens, Filip., Sasovova, Zuzana \& Labianca, Guiseppe Joe: 2013 "A Social Network Perspective On Turnover Intentions: The Role of Distributive Justice and Social Support", Human Resource Management, 52 (4), 561-584.

Somuncuoğlu, Demet: 2005 "Duygusal Zekâ Yeterliliklerinin Kuramsal Çerçevesi ve Egitimdeki Rolü”, Kâzım Karabekir Eğitim Fakültesi Dergisi, Sayı 11, 269-293.

Sparrow, Tim \& Knight, Amanda: 2006 Applied EI: The Importance of Attitudes In Developing Emotional Intelligence, Jossey-Bass Imprint, 3-312.

Suárez-Mendoza, Maria Jesús \& Zoghbi-Manrique-de-Lara, Pablo: 2007 “The Impact of Work Alienation On Organizational Citizenship Behavior In The Canary Islands", International Journal of Organizational Analysis, 15 (1), 2007, 56 - 76.

Swift, Michele L \& Virick, Meghna: 2013 Perceived Support, Knowledge Tacitness, and Provider Knowledge Sharing", Group \& Organization Management, 38 (6), 717-742.

Synder, Mark: 1974 "Self-Monitoring of Expressive Behavior", Journal of Personality and Social Psychology, 30 (4), 526-537.

Şengül, Arzu: 2009 "Hizmet İşletmelerinde Yüksek İlişki Kalitesine Ulaşılmasında Sınır Birim İşgörenlerinin Duygu İşçisi Olarak Değerlendirilmesi”, Ege Akademik Bakış, 9 (4), 11931211.

Şimşek, M. Şerif., Çelik, Adnan., Akgemici, Tahir \& Fettahlığlu, Tamara: 2006 “Örgütlerde Yabancılaşmanın Yönetimi Araştırması, 14. Ulusal Yönetim ve Organizasyon Kongresi, 569- 
587.

Şimşek, Hüseyin., Balay, Refik \& Şimşek, A. Salih: 2012 “İlköğretim Sınıf Öğretmenlerinde Mesleki Yabancılaşma”, Eğitim Bilimleri Araştırma Dergisi, 2 (1), 2012, 53 - 72.

Şişman, Mehmet \& Turan, Selahattin: 2004 "Bazı Örgütsel Değişkenler Açısından Çalışanların İş Doyumu ve Sosyal - Duygusal Yalnızlık Düzeyleri (MEB Şube Müdür Adayları Üzerinde Bir Araştırma)", Osmangazi Üniversitesi Sosyal Bilimler Dergisi, 5 (1), 117-128.

Tangney, June P., Baumeister, Roy F \& Boone, Angie Luzio: 2004 "High Self-Control Predicts Good Adjustment, Less Pathology, Better Grades, and Interpersonal Success", Journal of Personality, 72 (2), 271-322.

Tardy, Charles H.: 1985 "Social Support Measurement", American Journal of Community Psychology, 13 (2), 187-202.

Taviss, Irene: 1969 "Changes In The Form of Alienation: The 1900's vs. The 1950's", American Sociological Review, 34 (1), 46-57.

Tekingündüz, Sabahattin., Kurtuldu, Aysu \& Eğilmez, Çiğdem: 2016 "Sosyal Destek, İşe Yabancılaşma ve İş Stresinin İşgören Performansı Üzerindeki Etkisinin İncelenmesi”, International Journal of Human Sciences, 13 (1), 683-694.

Temizkaya, Ergun: 2015 "Modernite ve Postmodernite: Bazı Parametreler Açısından Bir Yaklaşım”, Akademik Hassasiyetler Dergisi, Sayı 4, 177-207.

Tepeci, Mustafa \& Pala, Tuğba: 2016 "The Effects of Job-Focused and Employee-Focused Emotional Labor On Burnout In The Hospitality Industry In Turkey", Journal of Global Strategic Management, 10 (2), 95-105.

Tett, Robert P., Fox, Kevin E \& Wang, Alvin: 2005 "Development and Validation of A Self-Report Measure of Emotional Intelligence As A Multidimensional Trait Domain”, Personality and Social Psychology Bulletin, 31 (7), 859-888.

Tezcan, Mahmut: 1997 Gençlik Sosyolojisi ve Antropolojisi Araştırmaları, Ankara Üniversitesi Eğitim Bilimleri Fakültesi Yayınları, No 178, 1-196.

Thijssen, Peter: 2012 "From Mechanical To Organic Solidarity, and Back: With Honneth Beyond Durkheim", European Journal of Social Theory, 15 (4), 454-470.

Thoits, Peggy A.: 1985 "Social Support and Psychological Well-Being: Theoretical Possibilites", Social Support: Theory, Research and Applications, Ed. Sarason, I. G ve Sarason, B. R., NATO ASI Series, Series D: Behavioral and Social Sciences, No 24, 3-519.

Thompson, Lanny Ace: 1979 "The Development of Marx's Concept of Alienation: An Introduction", Mid-American Review of Sociology, 4 (1), 23-38.

Thoms, Peg., Moore, Keirsten S \& Scott, Kimberly S.: 1996 "The Relationship Between Self-Efficacy For Participating In Self-Managed Work Groups and The Big Five Personality Dimensions", Journal of Organizational Behavior, 17 (4), 349-362.

Timmers, Monique., Fischer, Agneta H \& Manstead, Antony S. R.: 1998 "Gender Differences In Motives For Regulating Emotions”, Personality and Social Psychology Bulletin, Sayı 24, 1998, 974 - 985.

Tokat, Bülent: 1999 “Örgütlerde Çatışma ve Çatışmanın Yönetimi”, Dumlupınar Üniversitesi Sosyal Bilimler Dergisi, Sayı 1, 23-40.

Topateş, Hakan: 2009 “Araçsallaştırılmış Bir Kavram Olarak Sosyal Dışlanma”, Çalışma ve Toplum Dergisi, 23 (4), 115-130.

Toyama, Hiroyuki \& Mauno, Saija: 2017 "Associations of Trait Emotional Intelligence With Social Support, Work Engagement, and Creativity In Japanese Eldercare Nurses", Japanese Psychological Research, 59 (1), 14 - 25.

Tralau, Johan: 2005 "The Effaced Self In The Utopia of The Young Karl Marx", European Journal of Political Theory, 4 (4), 393-412.

Tummers, Lars \& Dulk, Laure Den: 2013 “The Effects of Work Alienation On Organizational Commitment", Work Effort and Work-To-Family Enrichment, Journal of Nursing Manage- 
ment, 21 (6), 850-859.

Turan, Mehmet \& Parsak, Gülşah: 2011 "Yabancılaşma ve İş Tatmini İlişkisi: Bir Devlet Üniversitesi İdari Personeli Üzerinde Araştırma”, Çukurova Üniversitesi Sosyal Bilimler Enstitüsü Dergisi, 20 (2), 1-20.

Turgut, Tülay \& Kalafatoğlu, Yaprak: 2016 “İşe Yabancılaşma ve Örgütsel Adalet”, İş, Güç Endüstri İlişkileri ve İnsan Kaynakları Dergisi, 18 (1), 27-46.

Turner, Bryan S.: 2009 Classical Sociology, SAGE Publications, 1-291.

Tutar, Hasan: 2007 "Katı Olan Her İş Sanallaşıyor veya İşgörenin Artan Yalnızlığı Üzerine: Kuramsal Bir Yaklaşım”, “İş,Güç” Endüstri İlişkileri ve İnsan Kaynakları Dergisi, 9 (2), 116-141.

Tutar, Hasan: 2010 "İ̧̧̧ören Yabancılaşması ve Örgütsel Sağlık İlişkisi: Bankacılık Sektöründe Bir Uygulama”, Ankara Üniversitesi Siyasal Bilgiler Fakültesi Dergisi, 65 (1), 175-204.

Uchino, Bert N., Cacioppo, John T., Malarkey, William., Glaser, Ronald \& Kiecolt-Glaser, Janice K.: 1995 "Appraisal Support Predicts Age-Related Differences In Cardiovascular Function In Women", Health Psychology, 14 (6), 556-562.

Uçel, Ela Burcu., Günerergin, Mert \& Cerit, A. Güldem: 2010 "An Empirical Study of The Relationship Between Normlessness, Business Ethics and Social Responsibility", African Journal of Business Management, 4 (18), 3947-3956.

Uğur, Adem \& Erol, Zehra: 2015 “Örgütlerde Kritik Sorun Kaynağı Olarak İşe Yabancılaşma, Yabancılaşma ve Bürokrasi Arasındaki İlişkiye Yönelik Kavramsal Bir Yaklaşım”, Kastamonu Üniversitesi İktisadi ve İdari Bilimler Fakültesi Dergisi, Say1 8, 182-192.

Unger, Darlene D.: 1999 "Workplace Supports: A View From Employers Who Have Hired Supported Employees", Focus On Autism and Other Developmental Disabilities, 14 (3), 167 179.

Usul, Hayrettin \& Atan, Aysel: 2014 "Sağlık Sektöründe Yabancılaşma Düzeyi”, Karamanoğlu Memetbey Üniversitesi Sosyal ve Ekonomik Araştırmalar Dergisi, 16 (26), 1-10.

Ünal, Uğur: 2017 “Turist Rehberlerinin Duygusal Emek Düzeyi ve İşe Yabancılaşmalarının Tükenmişlik Üzerine Etkisi”, Nevşehir Hacı Bektaş Veli Üniversitesi Sosyal Bilimler Enstitüsü, Yüksek Lisans Tezi, 1-104.

Ünsar, A. Sinan \& Karahan, Derya: 2011 "Yabancılaşmanın İșten Ayrılma Eğilimine Etkisini Belirlemeye Yönelik Bir Alan Araştırması", S.Ü. İ̇BF Sosyal ve Ekonomik Araştırmalar Dergisi, 15 (21), 361-378.

Vega, Gina \& Brennan, Louis: 2000 "Isolation and Technology: The Human Disconnect", Journal of Organizational Change Management, 13 (5), 468-481.

Vikan, Arne: 2017 A Fast Road To The Study of Emotions, Springer International Publishing, 1-112.

Walton, Richard E.: 1973 “Quality of Working Life: What Is It?”, Sloan Management Review, 15 (1), 11-21.

Watson, David., Clark, Lee Anna \& Tellegen, Auke: 1988 "Development and Validation of Brief Measures of Positive and Negative Affect: The PANAS Scales", Journal of Personality and Social Psychology, 54 (6), 1063-1070.

Wechsler, David: 1958 The Measurement and Appraisal of Adult Intelligence, The Williams \& Wilkins Company, 3-297.

Weiner, Bernard: 1986 An Attributional Theory of Motivation and Emotion, Springer-Verlag, 1-304.

Weisskopf, Walter A.: 1956 “The Sane Society By Erich Fromm”, Journal of Political Economy, 64 (6), 543-544.

Wendling, Amy E.: 2009 Karl Marx On Technology and Alienation, Palgrave MacMillan, 1-240.

Wharton, Amy S.: 2009 “The Sociology of Emotional Labor”, Annual Review of Sociology, Say1 $35,147-165$.

Willis, Cecil L.: 1982 “Durkheim's Concept of Anomie: Some Observation, Sociological Inquiry, 
$52(2), 106-113$.

Wills, Thomas A \& Shinar, Ori: 2000 "Measuring Perceived and Received Social Support", Social Support Measurement and Intervention, Ed. Sheldon Cohen, Lynn G. Underwood, Benjamin H. Gottlieb, Oxford University Press, 3-345.

Wolff, Kurt H.: 1950 The Sociology of Georg Simmel, The Free Press, 3-445.

Wondra, Joshua D \& Ellsworth, Phoebe C.: 2015 "An Appraisal Theory of Empathy and Other Vicarious Emotional Experiences”, Psychological Review, 122 (3), 411-428.

Wong, Chi Sum\& Law, Kenneth S.: 2002 "The Effects of Leader and Follower Emotional Intelligence On Performance and Attitude", The Leadership Quarterly, Sayı 13, 243-274.

Wróbel, Monika: 2013 "Can Empathy Lead To Emotional Exhaustion In Teachers? The Mediating Role of Emotional Labor", International Journal of Occupational Medicine and Environmental Health, 26 (4), 581-592.

Wróbel, Monika: 2017 "Emotional Affectivity", Encyclopedia of Personality and Individual Differences, 1-5.

Wu, Tsung Yu \& Hu, Changya: 2013 "Abusive Supervision and Subordinate Emotional Labor: The Moderating Role of Openness Personality", Journal of Applied Social Psychology, Say1 43, 956-970.

Wu, Xue., Shie, An Jin \& Gordon, David: 2017 "Impact of Customer Orientation On Turnover Intention: Mediating Role of Emotional Labour”, International Journal of Organizational Analysis, 25 (5), 909-927.

Yadisaputra, Michael: 2015 “The Role of Emotional Intelligence and Emoional Labor Among Frontline Employees In Casino Hotel Macao", International Journal of Tourism Sciences, 15 (1-2), 44-58.

Yalçın, Aslı: 2010 "Emotional Labor: Dispositional Antecedents and The Role of Affective Events", Middle East Technical University, Master of Science In The Department of Psychology, 1-141.

Yang, Seung Bum \& Guy, Mary E.: 2015 “Gender Effects On Emotional Labor In Seoul Metropolitan Area", Public Personnel Management, 44 (1), 3-24.

Yıldırım, İbrahim: 1997 "Algılanan Sosyal Destek Ölçeğinin Geliştirilmesi Güvenirliği ve Geçerliği”, Hacettepe Üniversitesi Eğitim Fakültesi Dergisi, Cilt 13, 81-87.

Yıldırım, Tamer: 2010 "Ludwig Andreas Feuerbach’ın Yansıtma Din Teorisi ve Eskatoloji Eleştirisi”, Şırnak Üniversitesi İlahiyat Fakültesi Dergisi, 1 (1-2), 65-85.

Yıldırım, Mehmet Halit \& Erul, Emel Eylül: 2013 "Duygusal Emek Davranışının İşgörenlerin Tükenmişlik Düzeylerine Etkisi”, Organizasyon ve Yönetim Bilimleri Dergisi, 5 (1), 89-99.

Yıldırım, Mustafa \& Türker, Nazlı: 2018 "The Effect of Emotional Labor On Work Alienation: A Study At Hotel Businesses”, Journal of Business Research-Turk, 10 (3), 606-621.

Yıldız, Halil: 2010 “Çalışma Üzerine Sosyolojik Perspektif”, Sosyal Siyaset Konferansları Dergisi, 58 (1), 129-161.

Yıldız, Fatma Zehra: 2017 “Duygusal Emek ve Yabancılaşma İlişkisi: Kabin Memurları Örneği”, Sakarya Üniversitesi Sosyal Bilimler Enstitüsü, Yüksek Lisans Tezi, 1-102.

Yılmaz, Sadi \& Sarpkaya, Pınar: 2009 “Eğitim Örgütlerinde Yabancılaşma ve Yönetimi”, Uluslararası İnsan Bilimleri Dergisi, 6 (2), 314-333.

Yin, Hong Biao., Lee, John Chi Kin., Zhang, Zhong Hua \& Jin, Yu Le: 2013 "Exploring The Relationship Among Teachers' Emotional Intelligence, Emotional Labor Strategies and Teaching Satisfaction", Teaching and Teacher Education, Sayı 35, 137-145.

Yin, Hongbiao: 2015 “The Effect of Teachers' Emotional Labour On Teaching Satisfaction: Moderation of Emotional Intelligence", Teachers and Teaching: Theory and Practice, 21 (7), 789-810.

Yüksel, Hasan: 2014 "Yabancılaşma Kavramı Paralelinde Emeğin Yabancılaşması ve Sonuçları”, Abant İzzet Baysal Üniversitesi Sosyal Bilimler Enstitüsü Dergisi, 14 (14), 159-188. 
Zavaleta, Diego., Samuel, Kim \& Mills, China: 2014 "Social Isolation: A Conceptual and Measurement Proposal", Oxford Poverty \& Human Development Initiative (OPHI), Say1 6, 1-62.

Zhang, Qin \& Zhu, Weihong: 2008 "Exploring Emotion In Teaching: Emotional Labor, Burnout, and Satisfaction In Chinese Higher Education", Communication Education, 57 (1), 105-122.

Ziller, Robert C.: 1969 “The Alienation Syndrome: A Triadic Pattern of Self-Other Orientation", Sociometry, 32 (3), 287-300.

Zimet, Gregory D., Dahlem, Nancy W., Zimet, Sara G \& Farley, Gordon K.: 1988 “The Multidimensional Scale of Perceived Social Support”, Journal of Personality Assessment, 52 (1), $30-41$. 